Article

\title{
Crux Christi Sit Mecum: Devotion to the Apotropaic Cross
}

\section{Kaja Merete Haug Hagen}

The Faculty of Theology, University of Oslo, P.O. Box 1023 Blindern, NO-0315 Oslo, Norway; kajamh@icloud.com

Received: 27 September 2019; Accepted: 24 October 2019; Published: 30 October 2019

check for updates

\begin{abstract}
A late medieval paper amulet containing prayers to St. Dorothy and the Holy Cross was found in a demolished part of a medieval wooden stave church in Torpo, Norway. This article examines the content and the function of this textual amulet by placing it in a wider Scandinavian and Western European context. From the perspective of materiality and sensory-based religious practices, this article will explore the connection between the textual amulet found in Torpo and its relation to the now-lost large wooden cross in Torpo church, and to crosses believed to be wonderworking or miraculous in its proximity. By doing so, this study will shed light on the apotropaic and healing potential that the material and immaterial cross offered the pious in late medieval Norway. The last part of this article addresses the Post-Reformation theological understanding of the amulet, and its use and function in Lutheran Norwegian society.
\end{abstract}

Keywords: material devotion; holy matter; hagiosensorium; haptic devotion; amulets; devotional literature; the holy cross; wonderworking and miraculous images; apotropaic potential; reformation

\section{Introduction}

At the end of the nineteenth century, a late medieval textual amulet was found in the wooden church at Torpo in Norway. As many other textual amulets from the medieval Latin West, the prayer written on the Torpo amulet was addressed to the Holy Cross. How are we to understand this prayer? What was its function, and why has it, at some point, been placed inside the church under the floor boards?

The protective powers of the cross could be invoked through a plethora of media in medieval culture, not only by the use of amulets but also, for example, through prayer books, benedictions, in liturgy, as well as through encounters with crosses present in churches. The aim of this article is to understand more fully the potential embodied in the cross in late medieval culture through an intertextual and intermedial examination.

In this article, I will begin by examining the formal and textual properties of the amulet, before placing the Torpo amulet in a wider Scandinavian and European context. A comparative and contextual analysis will help us identify the lacunae of the text and contribute to a fuller understanding of the amulet's content, as well as of religious beliefs and amuletic practices in its original late medieval context. The next part of the article will explore the relation between the cross addressed in the amulet and the now-missing cross in the church of Torpo, as well as miraculous crosses in Torpo's proximity. Lastly, light will be shed on continuity and change regarding amuletic practices, wonderworking crosses and religious beliefs in post-Reformation society. 


\section{A Prayer Beneath the Wooden Floor Boards}

Torpo is situated in the mountainous part of southern Norway, where the valley of Hallingdal offers a passage between the eastern and western part of the country. In 1880, the old stave church at Torpo was to be demolished and replaced by a new church. The destruction of the stave church had already commenced but was interrupted as The Society for the Preservation of Norwegian Ancient Monuments intervened and bought the remaining part of the stave church. By that time, the chancel had already been torn down, but the nave was rescued (Christie and Christie 1981, p. 118) (Figure 1).

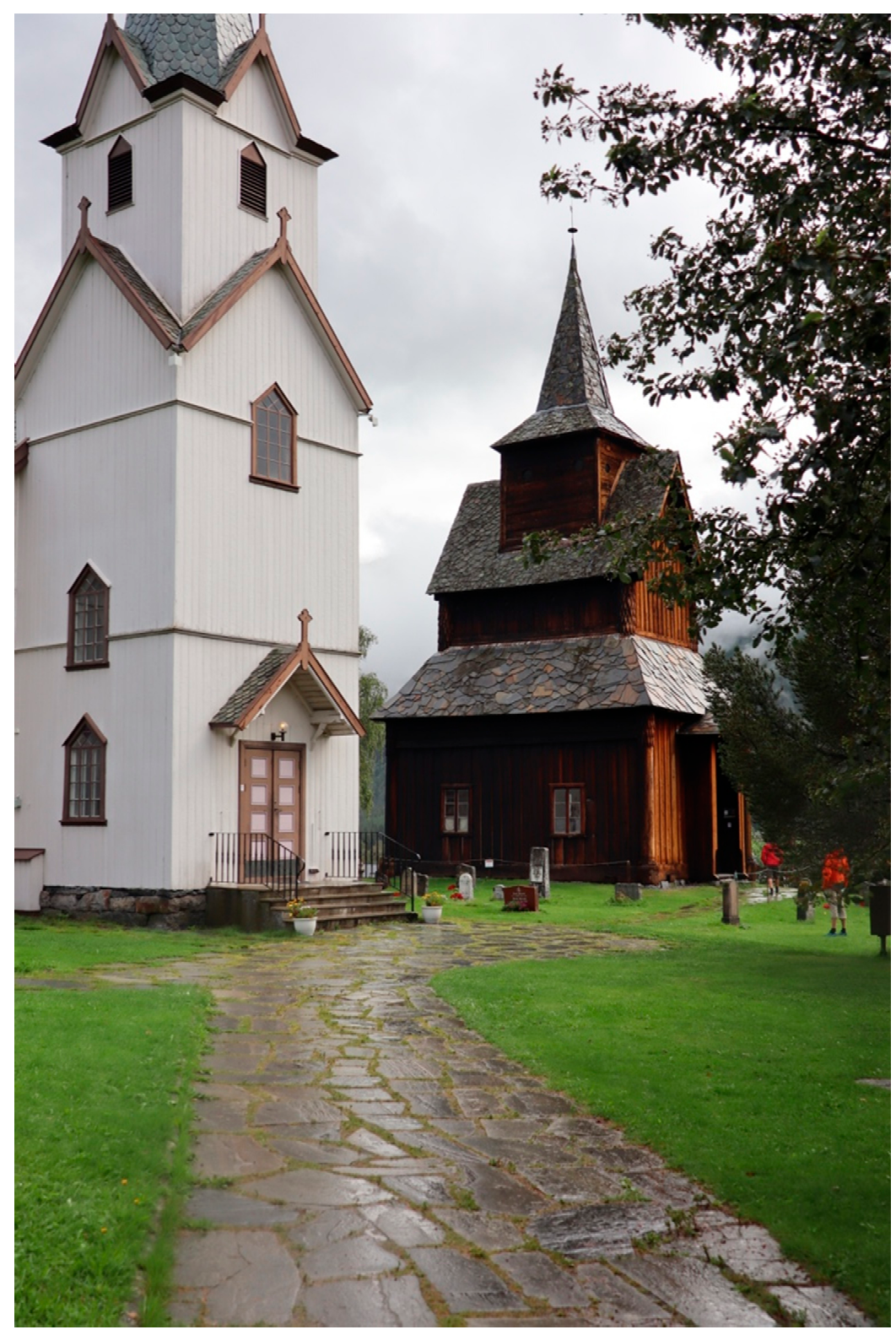

Figure 1. The wooden church of Torpo. Photo: Kaja M. H. Hagen.

During the demolition of the chancel, an old piece of paper, dated 1450-1500, was found. While the sources do not say exactly where in the chancel the paper was found, maybe it was placed beneath 
the wooden floorboards. ${ }^{1}$ On one side is drawn a sigillum Salomonis or Salomon's knot, a cross-shaped ornament with interlaced cross arms (Figure 2). The other side contains prayers in Latin (Figure 3):

[... ] virtuosa Dorathea vernans rosa mundi vita patens [ ... ] pro nobis speciose interuentrix graciosa ora pro nobis beata [ ... ] vt digni efficiamur gracia Christi omnipotens sempiterne [ ... ] [beate] Dorathee virg(i)nis tue tantam gloriam contulisti [ ... ] ssum vt eius intersseteptibus et meritis (ad) misericordiam peruenir [ . . ] domini nostri amen

Crux Christi sit mecum et ecclesia nostra crux Christi est enim quam [ ... ] adoro crux Christi est vita salus crux Christi superat gladium crux Christi [ ... ] nt vincula mortis crux Christi admirabile signum crux Christi sit mihi [ ... ] crux Christi sit mihi via virtutum cuper cruciem Christi aggrediar omne [ ... ]r crux Christi expandit omne bonum crux Christi aufferat a me omne [ ... ]l ... ]um crux Christi saluet me se et hodie super me ante me post [ ... ] ante me et post me et vbique me viderit antiquus hosttis [ ... ] [fu]giat a me jn nomine domini nostri Iesv Christi benedicat me Ihesus [ ... ] [sem-] piternus rex Judeorum [ ... ] per medium illorum ibat [ ... ] s Ihesus Christus crucifixus et filius dei viui benedicat me erigat. [ ... ] studiat Christus defendat me et dominus auertat a me omne [... ]um jn nomine patris et filii et spiritus sanctus amen. ${ }^{2}$

(Diplomatarium Norvegicum, 12, no. 266)

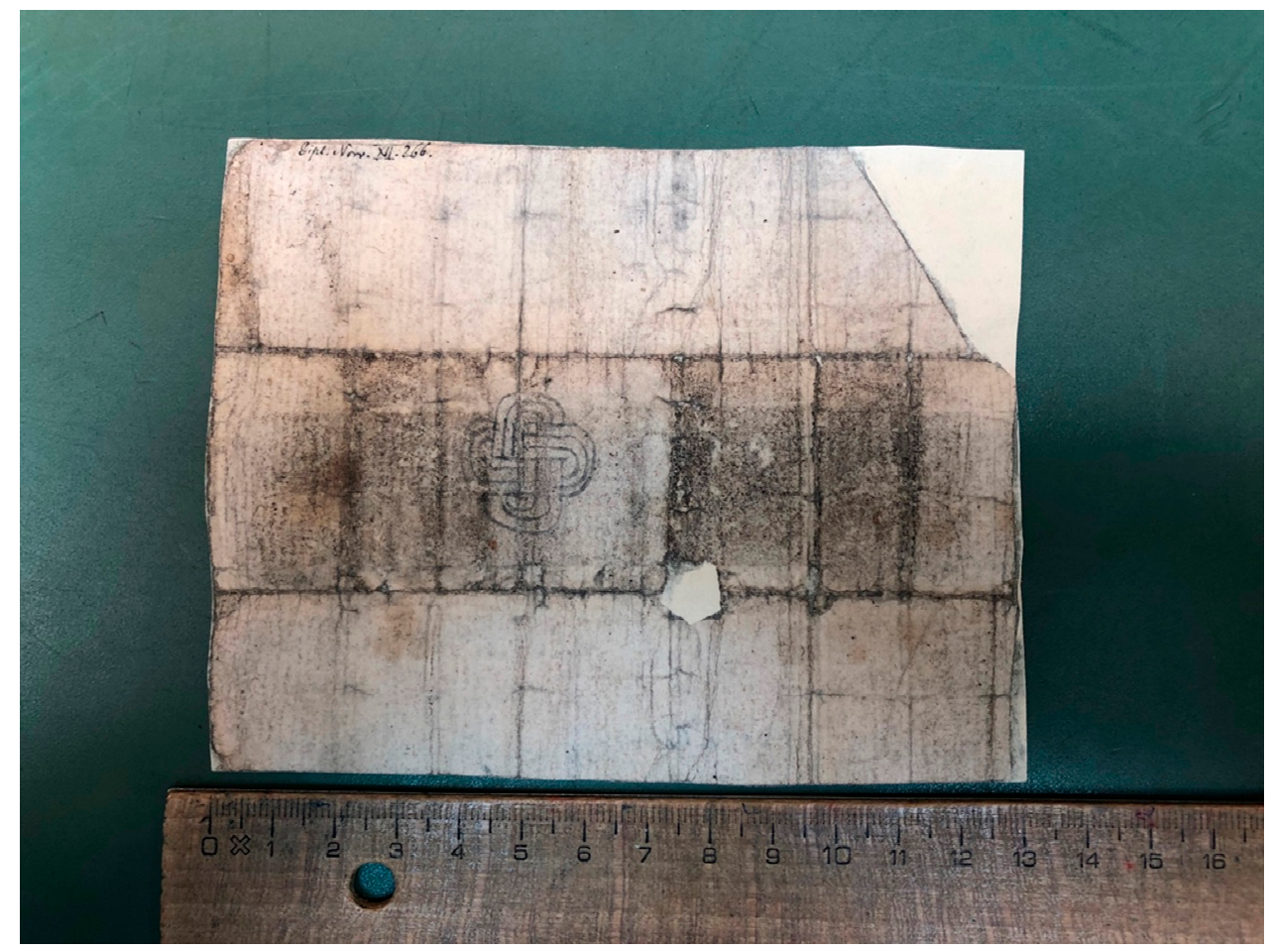

Figure 2. The amulet from Torpo, sigillum Salomonis or Salomon's knot. Ink on paper, 1450-1500. Photo: Kaja M. H. Hagen.

1 This suggestion is based on comparisons to other medieval amulets and a manuscript that, as we shall see later in the article, have been found under the floor boards in Norwegian churches.

2 I rely on the transcribed version in the Diplomatarium Norvegicum 12, no. 266.In the Diplomatarium Norvegicum 12, no. 266, lacunae are marked by a varying number of dots, and conjectures are marked with [ ... ]. In this article, illegible text is marked with $[\ldots]$, the conjectures suggested by the Diplomatarium are marked with $\{\ldots\}$, and conjectures suggested by Vemund Blomkvist and the author are marked with (... ). Conjectures are filled out based on Latin grammar and comparative material. 


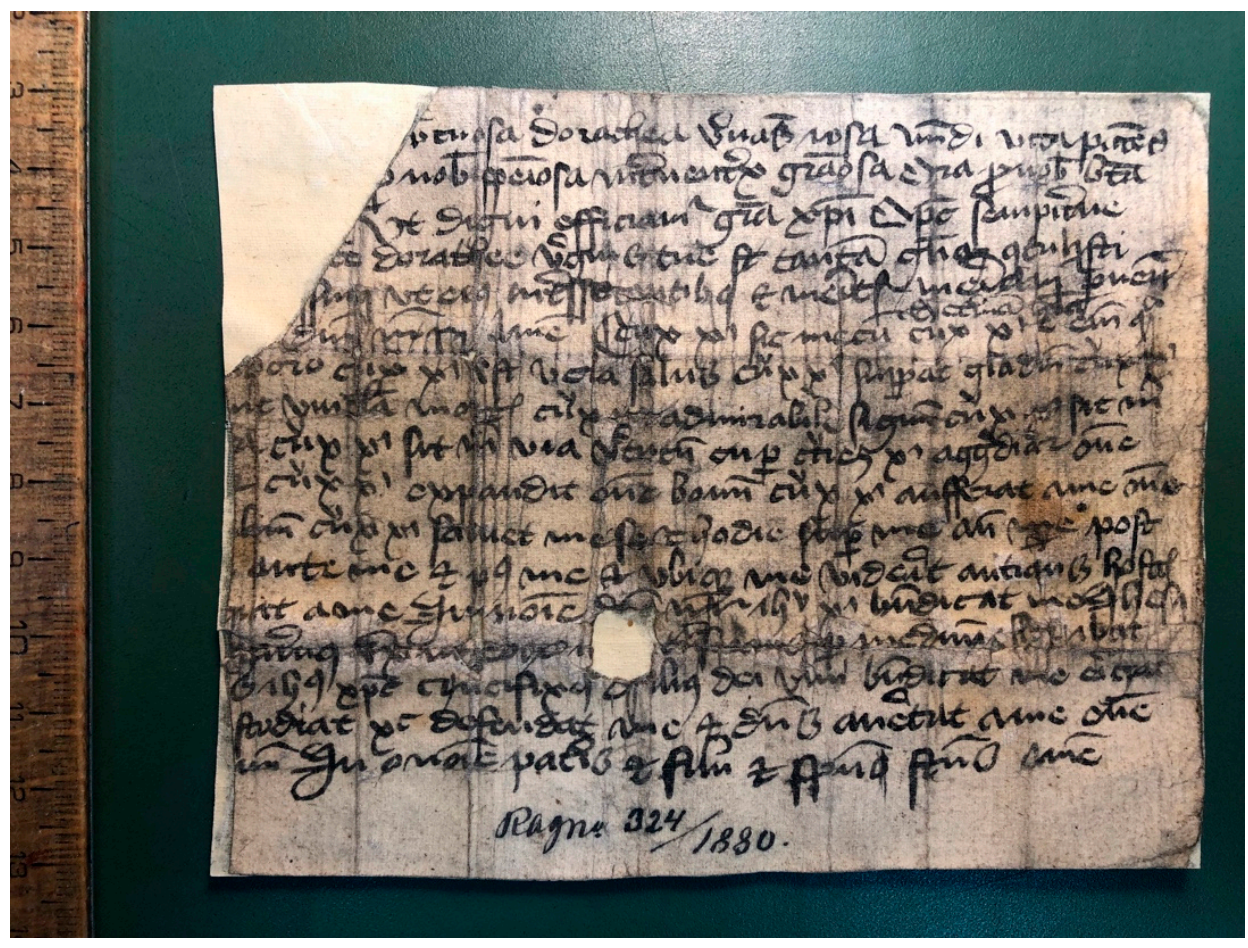

Figure 3. The amulet from Torpo, Latin prayers. Ink on paper, 1450-1500. Photo: Kaja M. H. Hagen.

Translated to English, ${ }^{3}$ the text on the Torpo prayer reads:

(Hail) virtuous (jewel), Dorothea, fresh open rose of pure life $[\ldots] !^{4}$ May you be a speaker for us, beautiful mediator full of grace. Pray for us, you blessed one [ ... ], that we may be made worthy of the grace of Christ. O, Almighty and Eternal, you gave [ ... ] such a great honour to your virgin Dorothea; that we through her intercessions and merits may attain mercy [ ... ] of our Lord. Amen.

May the Cross of Christ be with me and our Church, for the Cross of Christ is that which I (always) honour. The cross of Christ is life salvation. ${ }^{5}$ The Cross of Christ is stronger than the sword. The Cross of Christ is stronger than the chains of death. The Cross of Christ is a wondrous sign. May the Cross of Christ be for me [ ... ]. May the Cross of Christ be a way to virtues. With the Cross of Christ, I will face every [ ... ]. ${ }^{6}$ The Cross of Christ bestows upon me all good things. May the Cross of Christ take away from me all (evil). The cross of Christ saves me $[\ldots]$ and today over me before me behind [ ... ] before me and behind me and everywhere [... ] (When) the old fiend sees (it), may he flee from me in the name of our Lord Jesus Christ. Bless me, Jesus (of Nazareth) the eternal King of the Jews (passed) through the midst of them and went away. May Jesus Christ crucified and Son of the Living God bless me and raise [ ... ] may Christ care for me and defend me and may the Lord avert from me every evil. In the name of the Father and the Son and the Holy Spirit Amen.

Several parts of the text have been worn off and other parts are illegible. Despite the lacunae, the text is recognizable as a composite of two different prayers, the first to St. Dorothy addressed as the virtuous rose of the world and intercessor between God and humans, followed by a plea for help to make the

\footnotetext{
I am most grateful to Vemund Blomkvist who helped me with the translation of the text from Latin to English. Incorrect Latin: mundi vita should most likely be mundae vitae.

Incorrect Latin: vita salus should most likely be vera salus.

6 Incorrect Latin: cruciem should most likely be crucem.
} 
supplicant worthy of divine grace. The next part is addressed to the cross-Crux Christi sit mecum, the cross of Christ be with me-affirming the cross as the way to salvation, as the breaker of the chains of death, followed by an appeal to the cross, emphasizing its protective powers. The prayer to the cross ends with the name of Jesus, addressed as eternal king of the Jews, and a fragment which, as we shall see, is a quote from the Vulgate. The text ends with an invocation to Christ with a plea for protection from all evil.

When the amulet was registered in the Diplomatarium Norvegicum in the 1880s, it was accompanied by a summary, stating that the piece of paper was a "Praise (hymn to?) St. Dorothy and the cross of Christ, seemingly used as a sorcerous spell or amulet". An amulet was an object carried on the body for healing and/or protection against evil and could ward off diseases, or protect the bearer against the attacks of visible and invisible enemies (Kieckhefer 1989, p. 75). This article will seek to establish that the paper prayer was indeed an amulet, but was not, however, an object of sorcery or witchcraft as suggested in the Diplomatarium. The amulet was a devotional object, connecting God and the faithful.

The amulet is today kept at the National Archives in Oslo. The paper amulet is small, measuring only $13 \times 10.5 \mathrm{~cm}$. The paper has marks from wear and tear, some pieces around the outer edges and in the middle of the paper are missing altogether. Although undocumented, the paper has been subject to conservation after its rescue in the 1880s. During conservation, worn-off pieces have been replaced with a more brightly coloured paper, before the whole sheet has been covered in rice paper.

There are several vertical and horizontal, and darker, grid-structured lines that reveal the edges of the once folded paper. The part that made up the outer part of the object when folded is significantly darker that the rest. Following the original folding pattern, we can recreate the size and the shape of the folded piece of paper which would have measured only $3 \times 2 \mathrm{~cm}$. Paper is a fragile material; the middle missing part corresponds with one of the corners of the folded piece of paper.

\section{Theological Attitudes towards Amuletic Practices}

According to Don Skemer, the medieval belief in the efficacy of the written word to heal and protect was an inheritance from Antiquity (Skemer 2006, pp. 23-30). Amuletic practices were not, however, accepted in early Christianity. The use of textual amulets was condemned by the church fathers: St. Augustine related the use of amulets containing texts and sacred symbols to signs of pagan superstition, and St. Jerome equated textual amulets to Jewish phylacteries (Skemer 2006, pp. 32-35).

From the thirteenth century onwards, there was a division between black magic-magic associated with the devil—on the one side, and natural magic on the other. While black magic was seen as a perversion of religion and a turning away from God, natural magic relied on God in order to be successful (Kieckhefer 1989, pp. 8-12). Natural magic is probably best understood as a form of religion-based pre-modern science that tried to influence the hidden powers within nature. During the Middle Ages, the term "magic" seems to have been reserved for descriptions of pagan cults and demonic activities, such as frauds, deceptions and divinations of earth, water and air (Kieckhefer 1989, pp. 8-12). Attempts to influence nature in benign ways or to seek protection from dangers and daemons with the help of God, including through the use of amulets, was-although performed in a multitude of ways and far from universally accepted-not labelled as "magic" at all.

The theological opinion towards textual amulets became more nuanced during the course of the Middle Ages, resulting in a cautious acceptance of amulets and amuletic practices. St. Thomas Aquinas (122?-1274) allowed for a limited role for textual amulets as long as they were based on Christian texts. In his Summa Theologica, Thomas writes: "Divine words are no less efficacious when written than when uttered" (Aquinas n.d.b ST II-II, Q 96, Art.4). Conversely, texts that contained demonic invocations, mysterious names, meaningless words and unknown characters as well as symbols, were forbidden

7 Translated by the author. Original text: "Lovprisning af (Hymne til?) den hellige Dorothea og Christi Kors, vistnok benyttet som Trylleformular eller Amulet." 
as these would have fallen under the category of (black) magic. The only image Thomas accepted in amuletic context was that of a cross. According to Thomas, the amulets worked not because of the words put on paper or parchment, but as a result of people's prayer and devotion. Understood in this manner, Christians could use textual amulets as emblems or tokens of their own devotion and hope for God's protection: "it seems to be lawful to wear sacred words at one's neck, as a remedy for sickness or for any kind of distress" (Aquinas n.d.b, ST II-II, Q 96, Art.4). With correct content and venerated in the accepted manner, Thomas saw the use of amuletic texts as an equivalent to relics that could be kept in the domestic sphere. A textual amulet could thus be understood to be an expression of divine agency working through the material object (Aquinas n.d.b, ST II-II, Q 96, Art.4 and Skemer 2006, pp. 58-63). Although Thomas' view was contested by other theologians, he did provide an authoritative rationale for textual amulets. By the later Middle Ages, textual amulets were a widespread and common part of the Christian community (Skemer 2006, p. 73), believed to be an apotropaic weapon (Greek apotropaios, from apotrepein to avert, from apo- + trepein to turn) - a weapon used to ward off evil—in the fight against ever-lurking daemons and disasters.

\section{Haptic Devotion and Hagiosensorium}

The nuances regarding the theologically correct understanding and function of amulets articulated through scholastic arguments were most likely beyond the comprehension of most people. How then did the late medieval bearer of an amulet understand his or her use of such an object? It is safe to assume that the use of amulets with religious content was not understood as a form of demonic magic or actions in opposition to authoritative theology, but rather as an expression of piety and devotion.

During recent decades, the material turn in the humanities has offered art historians an alternative approach to the study of medieval religious objects. Theories and perspectives of materiality emphasize matter's ability to disclose the sacred to the medieval worshipper (Bynum 2011). The holy could be revealed in multiple ways. One was by allegorical interpretations of matter and phenomena, another was by looking at the likeness between matter and God. But the divine could also be instantiated in matter, as an actual presence. That the holy works in and through matter, was theologically established in Christian doctrines:

The doctrine of creation (that matter had been created by God), of the Incarnation (that God became human in the figure of Christ), of the resurrection of the body (that the material would in some way be present in heaven at the end of time and of divine omnipotence (that God could make matter behave in ways that violated the natural laws he also established (... ) (Bynum 2011, p. 154)

First and foremost, God could be experienced as a real presence through the sacraments. During the miracle of mass, the host became the flesh of Christ. Other forms of matter could also be instantiated by the divine: relics were believed to embody the virtue and a real presence of the saint. In addition to being placed in reliquaries, relics could be placed inside images, image frames and sculptures, blurring the line between relics and images (Belting 1994, pp. 297-303). By the later Middle Ages, even images without inserted relics were understood to be capable of embodying a divine presence (Belting 1994, pp. 208-304; Bynum 2011; Aavitsland 2015; and Jørgensen 2015, p. 29).

For the late medieval worshipper, the sacred was experienced through sensory mediation of holy matter. The human sensory apparatus was activated and structured to apprehend and identify God's presence in the world. Sensory experiences of earthly matter could disclose glimpses of the divine, a paradigm of perception modern scholars have labelled hagiosensorium (Jørgensen 2015, pp. 25-31 and Aavitsland 2015). The human sensorium — sight, hearing, smell, taste or touch—was considered dynamic, overlapping and interchanging. In his commentary on Aristotle's De Anima, Thomas wrote: "[The sense of touch] appears to be the least spiritual of the senses, though it is the foundation of all the others" (Aquinas n.d.a, Book II, Chp. XI, lectio 22, p. 517). The sense of touch was thus regarded as the basic component of all other senses. A haptic or tactile connection between object and body 
seems to have been an independent and adequate way of experiencing the holy (Skinnebach 2019). Laura K. Skinnebach has examined rubrics, found in medieval Danish devotional books. A rubric is a text informing the reader of the prayer's origin, apotropaic powers and/or instructions for use. Based on a study of this material, Skinnebach concludes that a medieval prayer could be performed in different ways: heard, read, seen—or carried. Skinnebach convincingly argues that prayers did not necessarily need to be read or even looked at, but could be performed by the body. She labels this form of devotion haptic prayer (Skinnebach 2019). According to Skinnebach, "The transference of protection to the body did not happen through the eyes or by reading, but through the sense of touch" (Skinnebach 2019, p. 8). In several rubrics, the physical presence between person and object was underlined in order to make the amulet more effective. In some cases, a whole devotional book could be carried or placed upon a person, analogous to a textual amulet, or a page from a devotional book could be excised and used as an amulet (Skinnebach 2019, p. 7). Both practices were forms of devotion where the connection between the pious and the material object was understood as a form of haptic prayer.

\section{Who Made the Amulet?}

Many medieval textual amulets were produced by priests, monks and clerics to combat sickness, injuries, demonic possession or for protection of mother and child during childbirth (Skemer 2006, pp. 79-81). Written sources reveal that textual amulets were used to help heal the sick both inside monastic infirmaries and outside the monastic sphere. We know that men and women of great authority made amulets, for example St. Hildegard of Bingen and St. Francis of Assisi (Skemer 2006, pp. 81-83).

In the diary of Luca Landucci (1436-1516), an apothecary from Florence, we can read of a trader of prayers, travelling around selling amulets to lay people. In order to promote his merchandise, the prayer seller presented himself as a miracle-worker-he climbed into a burning oven without being burned, he held his hand over candles, placed burning candles in his mouth and put his hand in a boiling pan of oil, all while urging the onlookers to watch. According to the diary, the popolo did indeed regard his actions as miracles, and in his diary, Landucci has written: "And this way he sold as many of those prayers as he could make" (Trexler 1972, p. 31). When it comes to the production of amulets, it seems like there was an expectation among lay people that the manufacturer had a special bond to God or served as a mediator between God and ordinary people, either as a man or woman of God or a miracle worker such as the Florentine fire-eater.

We do not know where or by whom the Torpo-amulet was produced-it could have been written by a local priest in Torpo or the surrounding area, but it could also have been transported from afar for local use, perhaps by a returning pilgrim. In Norway, we have no traces of such activities as described in Florence above. Still, it cannot be ruled out that a similar travelling vendor came to Torpo.

The original owner of the amulet is unknown, and the amulet might have had several owners through the years. Given the fact that the prayer was placed inside the local church, it is reasonable to assume that at least one of the owners of the prayer had a connection to Torpo.

\section{Ave Gemma and the Cross-Prayer}

The text on the Torpo-amulet is lacunose, and might at first glance be challenging to recognize and contextualize. In the following, a comparison to other preserved prayers will help us to understand the Torpo text more fully. The Torpo-amulet contains two prayers. The opening words of the first prayer are missing, with the first readable words being "( .. ) virtuosa Dorathea", a prayer to St. Dorothy. The second prayer is also fragmentarily preserved, but recognizable as a prayer to the cross. Both prayers are well known from other sources. As we shall see, there are several examples of both prayers appearing in amuletic form, as well as in lay devotional literature.

There are regrettably few extant written sources that reveal much about lay religious practices in pre-Reformation Norway. In order to find equivalent prayers and contextualization, we must look 
beyond the borders of present-day Norway. The prayer to St. Dorothy is found in Danish and Icelandic medieval devotional literature, as well as in the form of a medieval hymn (Nielsen 1946-1982, V. 84). In the Danish prayer book AM $41812^{\circ}$, we find the following Latin prayer:

Ave gemma virtuosa

dorothea vernans rosa

vite mundi patens glosa

sis pro nobis speciosa

interuentrix gloriosa ${ }^{8}$ (Nielsen 1946-1982, II. 327)

An Icelandic devotional book, AM 429 12mo, known as the Kirkjubæjarbók (the book from Kirkeby), contains legends of female martyrs (AM 429 12mo, 1490-1510.). In this manuscript, the same prayer appears (fol. 59v), accompanied by an image of St. Dorothy (fol. 48v) and the vita of the saint written in vernacular Norse (Wolf 1997, p. 62) (Figure 4).

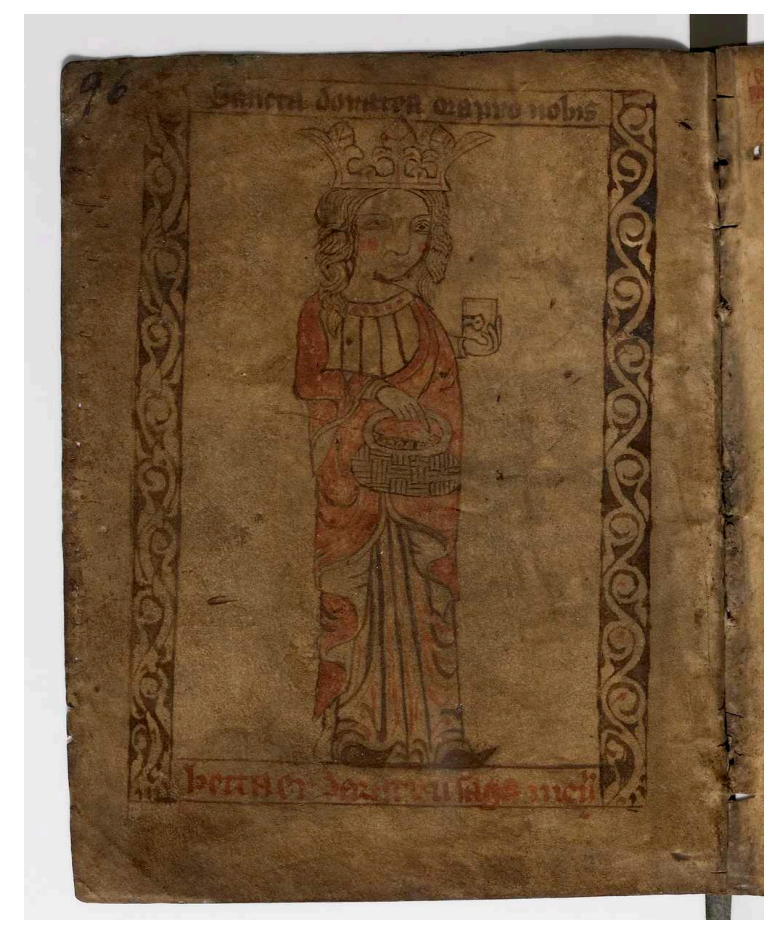

Figure 4. Image of St Dorothy, facsimile from AM 429 12mo (fol. 48v) dated between 1490-1510. Available at https://handrit.is/en/manuscript/view/en/AM12-429.

Apart from minor scribal and grammatical differences, the Danish and Icelandic versions are identical to the first part of the remaining fragments of the Torpo prayer. Based on these prayers, it is possible to suggest plausible conjectures to fill out many of the lacunae in the Ave Gemma-prayer in Torpo.

The second part of the Torpo prayer is known as the cross-prayer and was known throughout Western medieval Europe. In Denmark alone, ten versions are preserved (Skinnebach 2019, p. 5). The theme of all prayers is the same: the supplicant invokes the protection offered by the cross of Christ. Two of the extant Danish late medieval private devotional books, Anna Brade's prayer book

8 Translated to English by Vemund Blomkvist: Hail virtuous jewel, Dorothea, fresh open rose of pure life! May you be our glorious and beautiful mediator. 
(Nielsen 1946-1982, II. 33) and Johanne Nielsdatter's Book of Hours (Nielsen 1946-1982, I. 75), contain cross-prayers with striking similarities to the one found in Torpo. Although these two Danish prayers are in the vernacular, the order of phrases, rhythm and repetition show a strong resemblance to the Torpo-prayer. Anna Brade's cross-prayer reads:

The cross of our Lord Jesus Christ + be with me the cross of Jesus Christ + is the sign that I worship the cross of Jesus Christ + offers health the cross of Jesus Christ + surpasses all swords the cross of Jesus Christ + unties the chains of death the cross of Jesus Christ + is a steadfast weapon the cross of Jesus Christ + is a wonderous sign the cross of Jesus Christ + guard my life the cross of Jesus Christ + be my guide for all virtues/in the name of the holy cross I will follow everywhere the cross of Jesus Christ + means all good the cross of Jesus Christ $t$ take away all evil $t$ the cross of Jesus Christ + take away perpetual pain the cross of Jesus Christ theal me and be today before me/and over me/and after me so that the enemy which is the devil flees from me when he sees in me the name of our Lord Jesus Christ. ${ }^{9}$ (Nielsen 1946-1982, II. 33)

Karen Bille's book of hours contains yet another form of the cross-prayer (Nielsen 1946-1982, IV. 920). Although there are several linguistic differences between this prayer and to the two previously mentioned Danish versions and the Torpo prayer, the content is the same-all prayers call for the protection of the apotropaic cross.

If we look beyond the Danish material, the cross-prayer also appears in Latin in an extant handbook, Enchiridion Leonis Papae, supposedly written by Pope Leo III for Charlemagne. This book was printed in Mainz as late as 1633, and is a compilation of late medieval prayers that circulated in the Latin West. The prayer contains many components that also feature in the Torpo prayer:

Crux + Christi quam semper adoro, + Crux Christi sit in porta \& vera falus, + Crux Christi super et omnem gladium, +Crux Christi super \& vincula mortis, + Crux Christi sit pro me. + Crux Christi sit admirabile signum. + Crux Christi sit mihi potestas, + Crux Christi spondeat ante bonum mihi, + Crux Christi liberet me ab omni malo præsenti \& future, + per hoc signum Crucis sit mihi divinæ gratix omnis interceffio, + Crux Christi auferat à me omnes adversitates hujus mundi. + Crux Christi sit mecum, $\mathcal{E}$ salvet me, ante me $\mathcal{E}$ post me, quia antiquus diabolous ubi te videt, à me recedat, + per Crucis hoc signum, + fugiat à me omnis malignus sprirtus + pax Helo + tetragrammaton + didai $†$ pant aero elbry. + Jesus autem transiens per medium illorum ibat, fons, principlum, finis, veritas, omnipotens. † Amen. (Leo III. 1633, p. 119f)

The cross-prayer in the Torpo amulet ends with fragmentarily preserved text that reads: "Ihesus [ ... ] [sem-]piternus rex Judeorum [ ... ] per medium illorum ibat". This passage is a composite of two textual fragments. The first part Ihesus [ ... ] [sem-]piternus rex Judeorum recalls the inscription of the titulus of the cross of Christ, I.N.R.I. The phrase "Jesus Nazarenus rex Judeorum" was believed to be especially powerful in warding off evil. According to the commentary tradition, the titulus was associated with the words of Pilate, "what I have written, I have written". This statement has been interpreted as a testimony to the power of the written word: the text has been written, it will forever remain unchanged and it will persist (Hahn 2011, p. 196). In Torpo, the titulus-reference comes at the end of the cross-prayer, a feature consistent with Johanne Nielsdatter's Book of Hours where the cross-prayer ends with the phrase "Jesus of Nazareth, king of Jews" (Nielsen 1946-1982, I. 75). ${ }^{10}$ It

9 Translated by Laura K. Skinnebach and the author. Original text: "Wors herre ihesu christi kors + være meth mek Ihesu christi kors $+æ r$ thet tegn som iek tilbedher Ihesu christi kors + ær san helsen Ihesu christi korss † offuergaar alle swærdh Ihesu christi kors $†$ løser døtzcens bondh Ihesu christi kors + ær eth stadelicht vapn Ihesu christi kors + ær eth vnderlicht tegn Ihesu christi kors + værie mith liiff Ihesu christi kors + være myn veylederæ til allæ dygder/ $i$ thet hellige korsses naffn tha gaar iek alle veyæ Ihesu christi korss + vthtydher alt goth Ihesu christi kors + taghe fra mek alt onth + Ihesu christi kors + taghe fra mek ewynneligh pynæ Ihesu christi kors $\dagger$ hielæ mek oc være i dagh foræ mek/ oc offuer mek/ oc effter mek so ath wvennen som ær dieffuelen flyer fra mek ther han seer mek $i$ vors herre ihesu christi naffn."

10 Translated by the author. Original text: "Ihesus nazarenus iødæ kongæ", (Nielsen 1946-1982, I. 75). 
seems that this phrase enhanced the power of the cross-prayer, gave it authority and offered a verbal image of the titulus of the cross of Christ.

The latter part of the above text fragment is a biblical quote from the Vulgate, Luke 4:30, "autem transiens per medium illorum ibat" and recalls how Christ passed "through the midst of them", avoiding his enemies. This text was believed to bless the bearer with divine protection (Skemer 2006, p. 90) and is also found in other cross-prayers, for example in the Latin cross-prayer in the above-mentioned Enchiridion Leonis Papae.

\section{A Comparative Case: The Parchment Amulet}

In addition to the amulet from Torpo, there are several other extant Norwegian medieval textual amulets-some are small pieces of wood, others are made of lead. Some are in the shape of crosses, others rectangles (Diplomatarium Norvegicum 7, no. 441, Bang 1901/1902, pp. 470-74,

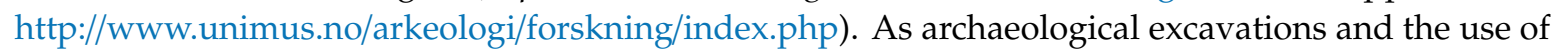
metal detectors increase, so does the number of amuletic finds ${ }^{11}$. Some of the textual amulets have inscriptions in Norse, but the majority are in Latin.

Of special interest for this study, is an amulet made of parchment, dated around 1400-1450, thus predating the Torpo amulet (Diplomatarium Norvegicum 7, no. 441, see also Aalholm 1957, p. 63 and Bang 1901/1902, pp. 470-74). The amulet is of unknown provenance and regrettably no information regarding where and when it was found is preserved. ${ }^{12}$ The single sheet of parchment measures ca. $20 \times 14 \mathrm{~cm}$ and, just like the Torpo amulet, has traces after folding. When folded, the parchment amulet would have measured ca. $5 \times 3.5 \mathrm{~cm}$. This amulet also has traces of wear and tear-the outer part of the folded amulet is darker than the rest of the sheet, and one corner of the folded amulet is dark from friction, handling and wear.

At the vertical and horizontal edges of the parchment are tiny holes which are most likely traces of preparation for writing. Vertical holes were made in order to organize text lines on the sheet, with each hole indicating where to start a new line. The horizontal lines on the bottom of the parchment are at first glance more confusing. The parchment has, however, been identified as a palimpsest, but the original writing is not possible to reconstruct (Gjerløw 1959, p. 63). The current format of the parchment is thus most likely secondary, a fragment excised from a larger page. The bottom of the current parchment would once have made up the left margin. Just as the manufacturer was believed to be in a favorable relation to God, so was the writing material of importance-pages from sacred books were believed to be particularly effective for amuletic purposes (Skemer 2006, pp. 127-30). Perhaps this parchment was once a part of a liturgical or devotional book.

The outer part of the amulet has an illustration consisting of three concentric circles, the largest with a diameter of $5.3 \mathrm{~cm}$ (Figure 5). Between the two outermost rings is an ornament, and between the two innermost circles is text: "Sanctus sanctus sanctus dominus deus sabaoth pleni sunt ce [li] et terra Gloria tua oseanna [in] excelsis agyos ys[Chir]os tetragramaton"13. In the innermost ring, a cross has been drawn. Between the wide cross arms is text that reads "Jesus Nazarenus rex Judeorum beniora biro buro berto". The first part is recognizable as the apotropaic phrase discussed above, but the last four words do not have an apparent meaning (Aalholm 1957, p. 59). A row of small crosses is drawn in red ink at the top—or bottom if the parchment is rotated—at the long side of the document.

11 Many of the amuletic registrations do not specify whether they contain text. Many lead objects have not been examined for texts as opening of a folded lead object will damage the object see (Imer and Olesen 2018). Furthermore, some databases only register amulets with runic inscriptions such as Samnordisk Runtextbas, http://www.nordiska.uu.se/forskn/samnord.htm. This amulet is kept at KUBEN, Aust-Agder museum and archive in the south of Norway.

13 I rely on the transcription by Aalholm (Aalholm 1957). Translated to English by Vemund Blomkvist: Holy, holy, holy (are you) the Lord God Sebaoth. The heavens and the earth are full of your glory. Hoseanna in the highest, holy strong tetragrammaton. The last words are in Greek. 


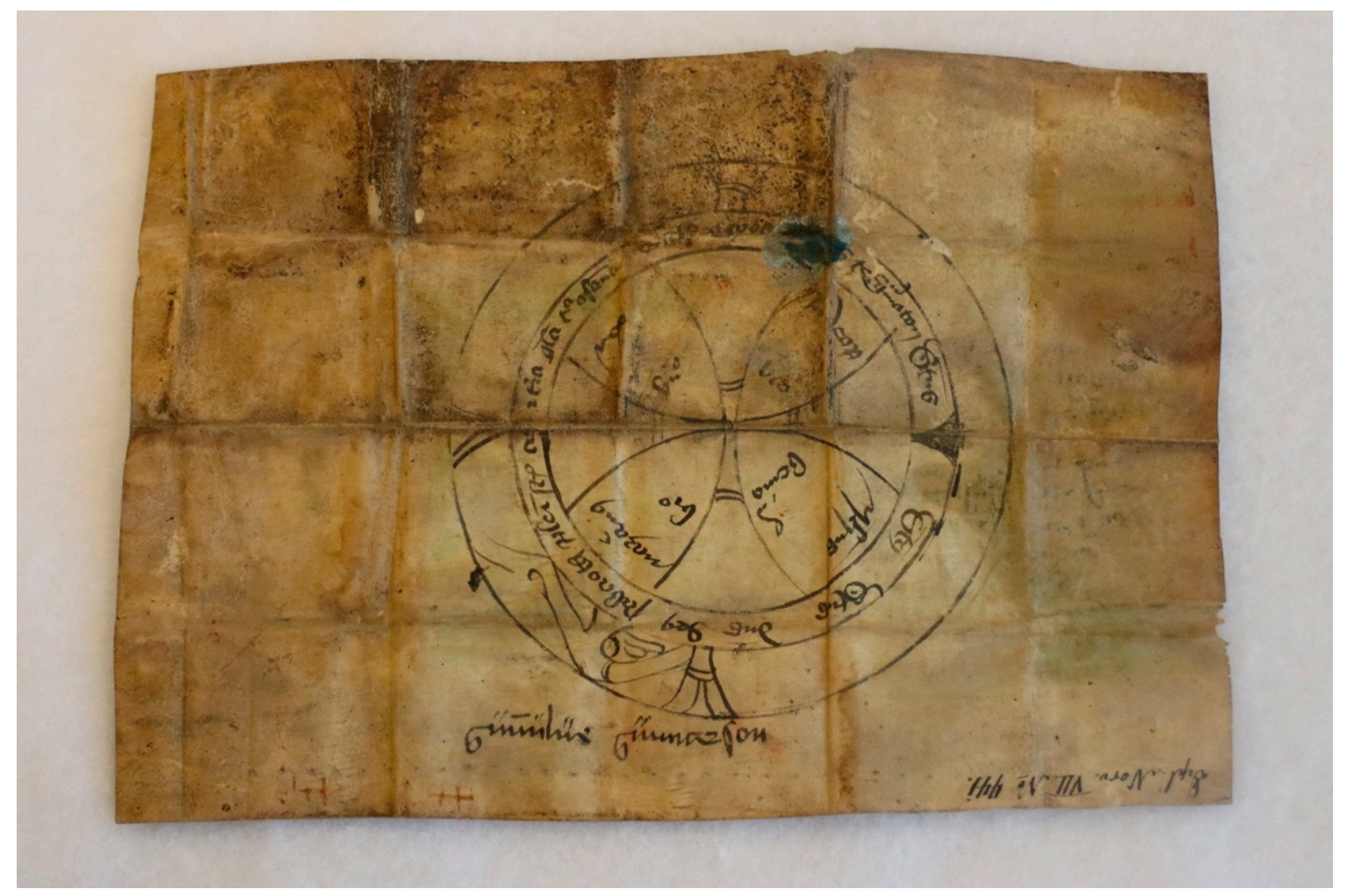

Figure 5. Amulet from Aust Agder, cross ornament. Ink on parchment, 1400-1450. Photo: Kaja M. H. Hagen.

The other side of the amulet is covered with text (Figure 6). The opening words from the Gospel of John were considered to be especially apotropaic, and the passage was frequently used in textual amulets (Skemer 2006, p. 84). The first text passage on the amulet is a paraphrase of the prologue of the Gospel of John. This passage is followed by a prayer to John the Baptist and a prayer to John the Evangelist, before a prayer to the cross appears:

crux bona crux dingna

Per omnia lingna benigna

tu me consignia

ne moriar morte malignia. ${ }^{14}$

Again, we see the cross invoked as an intercessor between God and man, capable of action, with protective qualities, able to keep a wicked death away from bearer. The text ends with an invocation to the many names of Christ in Latin and Greek.

14 Translated to English by Vemund Blomkvist: Good Cross, worthy Cross/Among all trees the most fruitful/Set your seal on me/That I not die an evil death. 


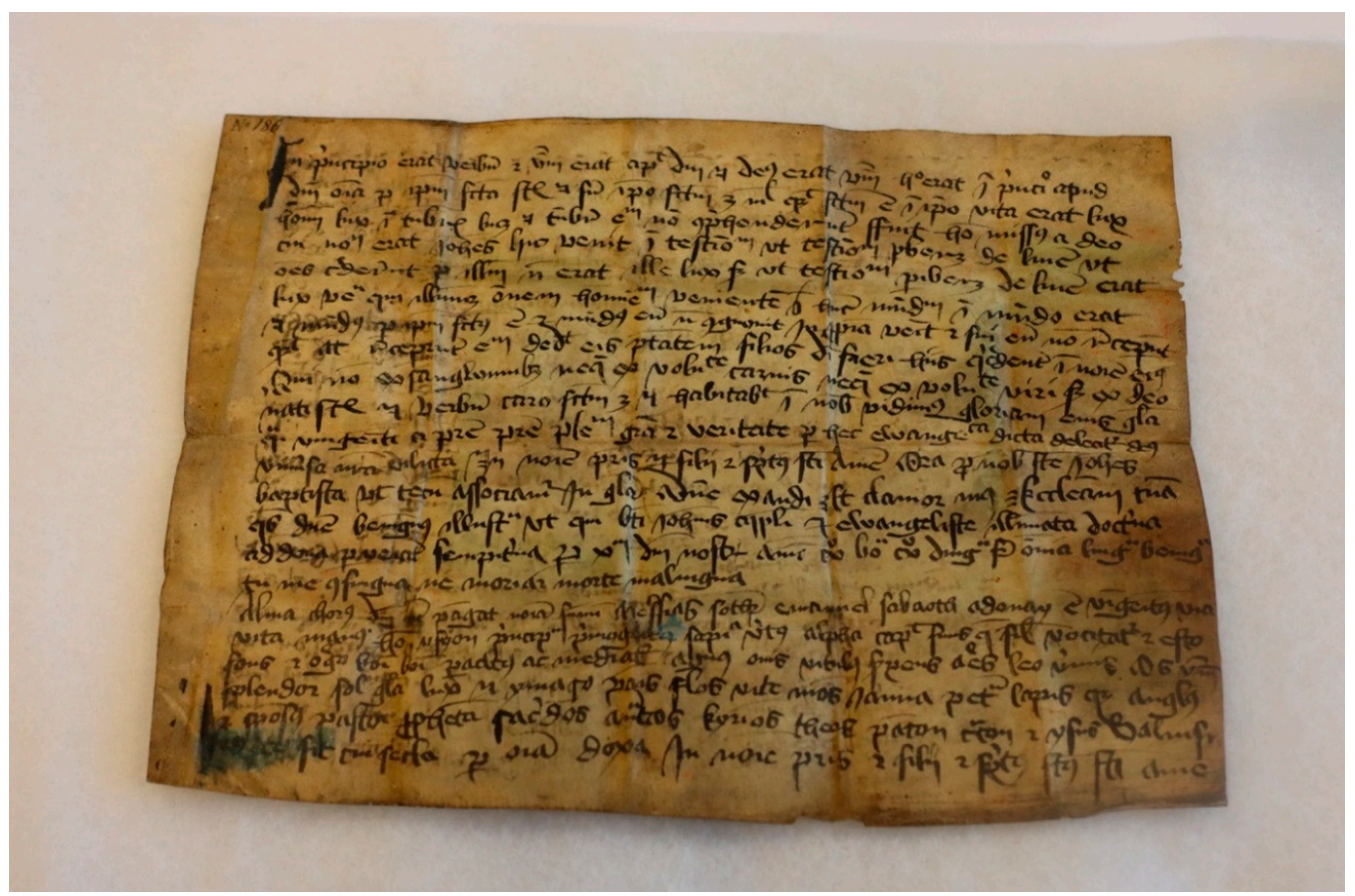

Figure 6. Amulet from Aust Agder, Latin text. Ink on parchment, 1400-1450. Photo: Kaja M. H. Hagen.

The prayer to the cross found in the parchment amulet is, however, not written in correct Latin. An explanation for the lack of proper Latin might have been the need for rhyme and rhythm which could have been regarded as more important than correct grammar. In both the Ave Gemma-prayer and the cross-prayer found at Torpo, rhyme and repetition are striking features. Rhyme, rhythm and/or repetition would have facilitated the recollection of the prayers and hence functioned as mnemotechnical strategies. We do not know if the original owner(s) of the Torpo prayer was a literate person, or if he or she knew Latin. Nonetheless, this does not imply that the bearer had no awareness of the content of the prayer. Rhyme and rhythm would have made recollection of a prayer easier, especially if the prayer had to be learned by heart in a language few had mastered. As mentioned above, many of the preserved Norwegian amulets have inscriptions in Latin. The choice of language was undoubtedly important-Latin, the ecclesiastical and sacred language, could have been believed to enhance the power of the prayer. The auditive aspects of the Latin language would have added to the words' semantic references, making the prayer a multi-sensory experience (Jessen and Sørensen 2015).

\section{Informative Rubrics: Information of Origin, Protective Powers and Instructions for Use}

As mentioned above, several of the extant Danish medieval prayers are accompanied by rubrics, explaining to the reader when, by whom and to whom the prayer was written, underlining the potential and the success of the prayer and/or providing the reader with instructions for use.

The origin of the cross-prayer is emphasized in both Anne Brade's and Karen Bille's devotional books - the texts state that this prayer was written by Pope Leo to Charlemagne. ${ }^{15}$ The supposed origin of this prayer can be traced back to the apocryphal legend of the Heavenly Letter. The legend of a holy letter accompanying certain prayers exists in different versions. In one version, the letter was written by Christ himself to King Abgar V of Edessa for protection. In other versions, the letter was sent by the Archangel Michael or St. George, and yet in others, like in the Danish devotional literature, the letter was presumedly written by Pope Leo III (Skemer 2006, pp. 99-105). The Latin cross-prayer

15 (Nielsen 1946-1982, II. 33). One of the original texts reads: "Item thenne efterscreffne bøn dictæde oc screff een helligh pawæ $i$ rom som hedh sanctus leo/oc sæde henne til syn brodher karll magnus om var konnyngh i franckkeriigæ (... )". 
in Enchiridion Leonis Papae was also accompanied by the Heavenly Letter. The papal origin and the protective powers of the prayers are analogous to the information found in the Danish material.

The papal-imperial origin undoubtedly served as proof of the cross-prayer's authority and the apotropaic potential of the prayer. The author of the prayer was the Holy Father himself. Needless to say, this information was of the highest importance for the understanding of the prayer as righteous, pious and effectual. That the prayer had been given to, presumably carried, and perhaps said, seen and heard by the most legendary and successful of kings in Europe, the Pater Europae Charlemagne, served as proof of its superiority, power and success. Furthermore, the prayer is presented as ancient, predating both the extant Scandinavian devotional prayers and the Torpo amulet by centuries, testifying to its established authority and power.

Not only the origin of the cross-prayer, but also its apotropaic power and instructions for use were included in both the Scandinavian devotional material and in the Enchiridion Leonis Papae. In the latter, under the heading Oraisons contre les perils $d u$ monde, it is stated that nothing bad would happen to the one who carried or read-portera ou lira-the cross-prayer (Leo III. 1633, p. 118). The Danish cross-prayers found in Anna Brade's and Karen Bille's devotional books, are accompanied by similar text ensuring the reader or bearer of its apotropaic power-the one who hears, sees or carries this prayer on his or her body, shall not drown, burn or die, and neither another person nor the devil can harm him or her (Nielsen 1946-1982, II. 33).

It was not only the cross-prayer that was accompanied by instructive rubrics or assurances of the power of the prayer. The above-mentioned Ave gemma-prayer in AM 418, $12^{\circ}$ follows directly after a rubric with the following text: "( . . ) If a woman is in pain during labour, and if she has this prayer on her body, the child will soon be born without permanent injury". ${ }^{16}$ St. Dorothy is the patron saint of gardeners, brewers and newlyweds, in addition to being the patron saint of midwives and women in labour. Perhaps the Torpo amulet also functioned as a birth-gridle, protecting the woman if carried on her body. Interestingly, the above instruction informs us that the prayer would not necessarily need to be read at all. Perhaps it was the material presence of the amulet, its proximity to the body and hence its haptic qualities that ensured the prayer's apotropaic power (Skinnebach 2019), or perhaps the presence of the amulet reminded the bearer of the content inside.

Textual amulets could be carried on the person either in a sewn-in pocket, a pouch, a small container or in other ways fastened to the body. Based on a survey of surviving rubrics, it seems like a default placement of an amulet for overall protection was to carry it around the neck. For specific injuries, an amulet could be placed on the body parts in question. For protection during pregnancy and delivery, the instructions as to where the woman was to bind the amulet could vary, for example over the abdomen, on the right knee, below her right breast or on the back (Skemer 2006, pp. 236-239). As the Torpo prayer is not accompanied by a written instructive rubric, we are left to compare it to the surviving Danish rubrics, and to study its material traces. As mentioned, the Torpo prayer measured only $3 \times 2 \mathrm{~cm}$ when folded, and was hence suitable for portable purposes. Some of the folded edges has vanished as a result of wear and tear. Paper is a fragile material that would most likely have deteriorated without any protective cover. Although no container or pouch has survived, it seems a fair assumption that it was indeed placed in such.

Given that so few written sources regarding lay devotional activity from the Norwegian Middle Ages have survived, the textual amulets are valuable for our understanding of the spiritual environment in the Middle Ages at the most northernerly corner of Europe. The amulets' existence testifies to a shared belief in the power and potential of the written word-and in the apotropaic potential of the cross-found throughout Western Christianity. During the Middle Ages, Norway was a fully integrated part of the European Christian community. The textual amulets testify to shared devotional

16 (Nielsen 1946-1982, II. 327). My translation. Original text: “( . . ) Oc hulcen qwinnæ som meth barn pynes oc hawer hun thenne bøn paa segh thet barn skal snarlighe fothes foruthen alt meen". 
ideals and activities found in other countries in the Latin West, the same prayers were said in Rome, in Denmark and in the remote parts of Norway.

\section{The Apotropaic Cross in Text and Image}

From the point of the discovery of the True Cross by dowager empress Helena in Jerusalem in 326, the cross was already linked to its healing capabilities. The widespread legends of testing of the True cross bear witness to the medieval understanding of its wonderworking potential. When Helena had difficulties verifying which cross was the cross of Christ, a bishop brought forward a dying woman who was miraculously healed in the presence of the holy wood. A similar story describes how a dead man was brought back to life when Christ's cross was brought forward (Jensen 2017, pp. 59-60). These legends were known all over Western Christianity, including in the north (Steinsland 2004). From the second half of the fourth century, the cross became a symbol associated with apotropaic and healing potential (Garipzanov 2018, p. 99).

The apotropaic qualities of the cross were also addressed during liturgy. In 1519, the archdiocese of Nidaros had a breviary printed, providing uniform liturgical instructions and texts for celebration of the divine office throughout the church province. The breviary illustrates how the cross was celebrated during the church year and how its apotropaic powers were underlined. For example, under In commemoratione sancte crucis the cross was revered as follows: "Hoc est namque sacrum signum, per quod vincimus malignum et fugamus vitium"17 (Sperber 2019, p. 533). That crosses could function as devotional tools or apotropaic shields was, therefore, not a trope reserved for textual amulets or devotional literature, but was also acknowledged by theological authorities, expressed in liturgical settings-as well as in images and sculpture.

The belief in the protective and healing power of the cross seems to be fundamental for the extant Norwegian amulets, and crosses were indeed present in various forms in most textual amulets, both as subject matter for the written prayer and as pictorial elements. Image and written texts seem to have had a mutually advantageous effect. Many textual amulets include drawn images of crosses, in line with Thomas Aquinas' pictorial instructions mentioned above. Crosses could take the form of simple or more ornamented graphic drawings and could be inscribed with names, such as the above-mentioned parchment amulet, while prayers could be formed in the graphic shape of crosses, and a series of different crosses could be juxtaposed (Skemer 2006, p. 200). Two of the other extant medieval Norwegian amulets are lead crosses with identical Latin inscriptions starting with "Ecce crucem domini, fugite partes adverse"18 (Bang 1901/1902, pp. 470-71). Crosses could also be drawn inside a text and could function as punctuation or, as seen above in the cross-prayer in Anne Brade's prayer book, as instruction to the reader to perform physical gestures at certain stages in the prayer, to make the sign of the cross upon the body. In this manner, the cross was present in the text, in image, and also, albeit briefly, as a bodily image.

As mentioned above, the backside of the Torpo prayer has a drawn symbol, sigillum Salomonis or Solomon's knot, a cross-shaped ornament with interlaced cross arms, measuring ca. $2.1 \times 2.3 \mathrm{~cm}$. During the Middle Ages, King Solomon was the ultimate source of wisdom, and was also believed to be capable of influencing nature (Davies 2012, p. 35). Solomon's knot had been associated with apotropaic powers since Antiquity, and was used as an ornamental motif in early Christian churches. The protective aspect of the Salomon's knot was understood as analogous to that of crosses (Garipzanov 2018, pp. 45, 103 and 110). The use of the Salomonic seal would have enabled the owner of the Torpo prayer to visualize the protective power of the amulet and hence facilitated the memory of the written content of the prayer on the inside. In this manner, seeing an image was analogous to reading, hearing or seeing the prayer inside.

17 Translated to English by Vemund Blomkvist: For this is a holy sign through which we conquer evil and dispel vice.

18 Translated to English by Vemund Blomkvist: Behold the Cross of the Lord! Flee, evil powers! 
When examining medieval devotional practices, the relationship between prayers, gestures, text and images was interdependent and interlaced. Not only amulets, but liturgical books and private devotional books also contained images of crosses and crucifixes accentuating the protective powers of the cross. In a fourteenth-century version of Speculum Humanae Salvationis is an illumination of Christ. In one hand, he holds the vexillum; in the other, he holds the cross with which he has pierced the fallen devil lying on the ground. With the holy cross, the sacrum signum, the devil is crushed and evil overthrown (Figure 7).

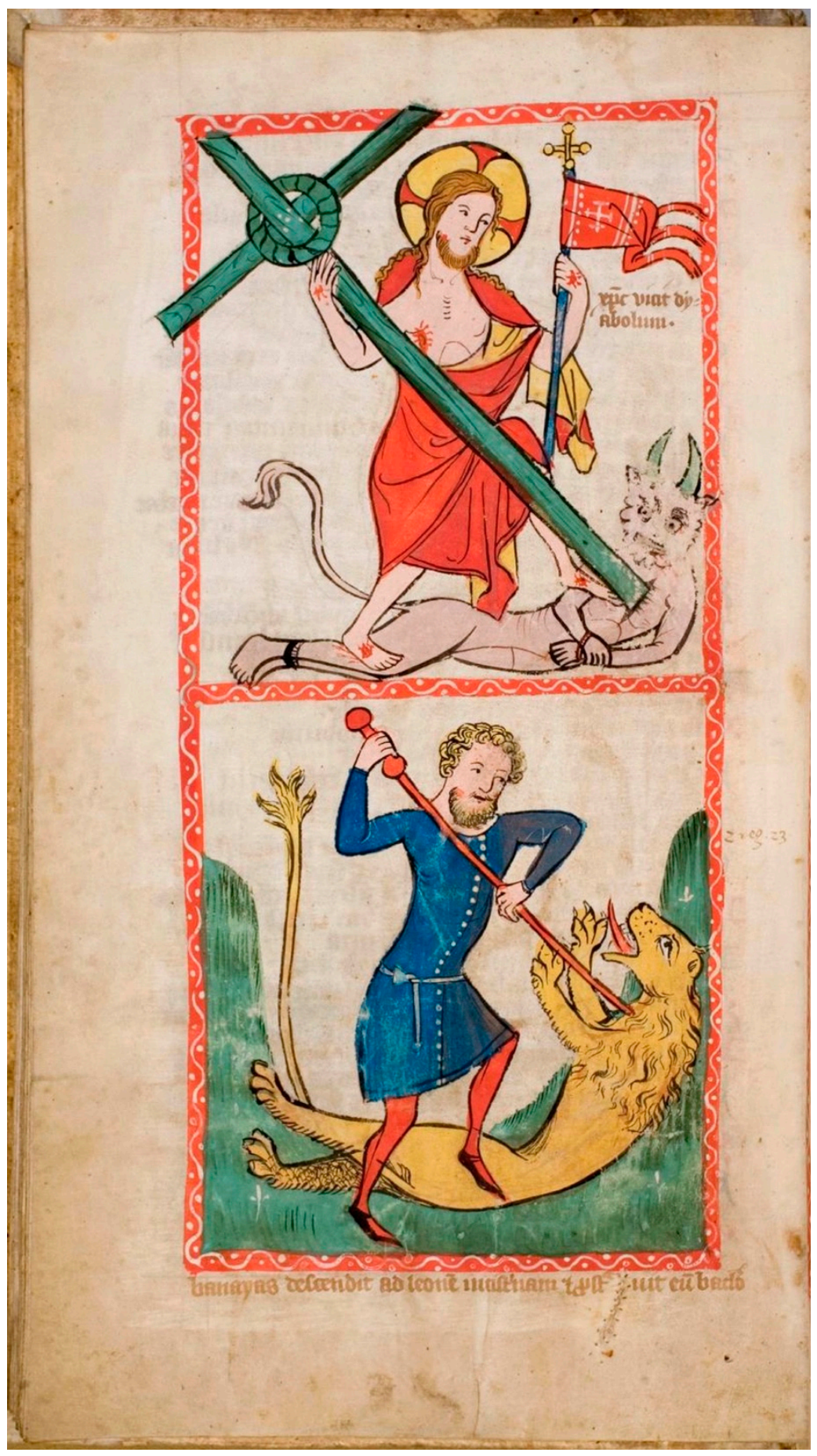

Figure 7. Christ. piercing the devil with the cross, facsimile from Speculum Humanae Salvationis, Hs 2505. Germany, ca. 1350. Available at http://tudigit.ulb.tu-darmstadt.de/show/Hs-2505/0108/image. 
According to the above-mentioned Enchiridion Leonis Papae, indulgence was given to those praying in front of an image of crucifix (Leo III. 1633, p. 154). It does not say what kind of image, but most likely a drawn image in an amulet, a painted illumination in a manuscript or a large crucifix inside a church were all understood as adequate images for gaining an indulgence. The next part of the article will further explore the Torpo text's relation to the large wooden cross in the church of Torpo and to wonderworking crosses in Torpo's proximity.

\section{The Wonderworking Crosses in Norway}

As the cross emerged as the prime Christian symbol, large crosses and crucifixes were consecrated and placed in churches and on altars. By the time the amulet in Torpo was made, the cross was omnipresent in churches across western Christianity. The cross was addressed as part of the liturgy, for example as seen above in the brevarium from Nidaros. In addition, the cross was celebrated and honoured on Good Friday and during yearly feasts of commemoration: the Invention of the Cross on 3 May and the Exaltation of the Cross on 14 September. The large crosses also served as focal points for individual devotion.

It is generally assumed that most churches in medieval Norway had a great crucifix. Within the borders of medieval Norway, around 1300 medieval churches, chapels and ecclesiastical houses are documented either in written sources or through archaeological evidence (Brendalsmo 2007; Karlsen 2013, pp. 33-34). It has been suggested that as much as 500 to 1000 churches should be added to this number, based on local tradition, church names, etc. (Bertelsen 2016, p. 54; Karlsen 2013, p. 33). These examinations indicate the medieval existence of at least 2000 churches and a corresponding number of great crosses. Today, 170 Norwegian medieval wooden polychrome crosses, crucifixes, and Calvary groups are preserved (Hohler 2017, pp. 47-55). Even if most of the Norwegian written sources from the Middle Ages are lost, there are numerous references to crosses that were connected to extra-liturgical cults or crosses believed be to wonderworking or miraculous. No less than 37 crosses owned land, received gifts and pilgrims or performed miracles (See for example Diplomatarium Norvegicum vol. 1 , no. 545 , vol. 2 , no. 825 , vol. 11 , no. 41 , vol. 18 , no 164 , vol. 21 , no. 1058 , vol. 23 , no. 69; Regesta Norvegica vol. 8, no. 284, vol. 8, no. 389, vol. 9, no. 1439; Huitfeldt 1879 pp. 22, 45, 75, 80, 103, 108, 110, 138, 451; Munch 1834a pp. 23, 24, 60, 81, 82, Munch 1834b; p. 92; Nicolaysen 1862-1866, p. 48; Skielderup 1572/1905 pp. 53-54; Nielsen 1885, p. 517). Given the meagre body of written sources, the actual number is most likely significantly higher.

One of the most renowned crosses in Norway was found in Røldal in the south of Norway, the miraculous sweat of which healed the faithful on Midsummer's Eve (Figure 8). The wonderworking cross in Røldal received pilgrims from far and near. Both Røldal and Torpo belonged to the bishopric of Stavanger. The bearer(s) of the Torpo prayer was assumedly familiar with the stories of the renowned wonderworking crucifix in Røldal.

By the later Middle Ages, tales of wonderworking crosses and crucifixes were widespread across western Europe. It has been argued that the many legends of miraculous crosses affected the perception of crosses and crucifixes in general-any cross had the potential of becoming a miraculous or wonderworking cross that could affect the lives of the pious (Cooper 2006, p 56). Perhaps this understanding was also valid for the local crucifix in Torpo church. 


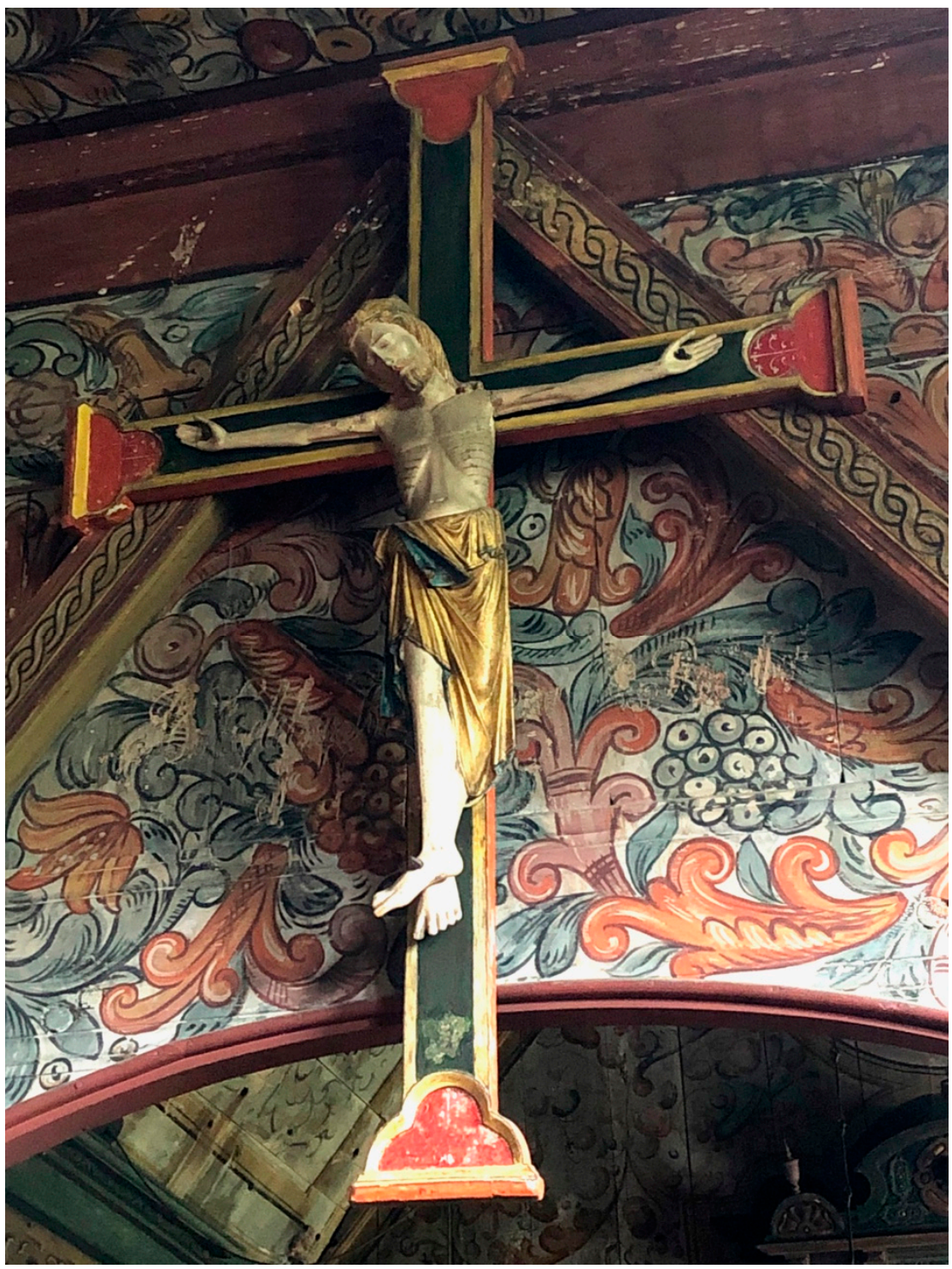

Figure 8. The Røldal Crucifix. 1240-1255. Cross H 157cm. Figure H 89 cm. Photo: Kaja M. H. Hagen.

\section{The Large Wooden Polychrome Crucifix in Torpo}

During the Middle Ages, individual devotion could take place both in the private sphere and in church, both during and outside of mass. Several extant Danish prayers instructed the reader to say specific prayers at specific times during mass (Skinnebach 2013, pp. 145-48). Instructions also show that private prayers were to be said in front of crucifixes. Such instructions likely referred to crucifixes of all forms, depicted in prayer books or amulets, hung on the wall in private homes or the large crucifix in a church. We cannot know if the owner of the Torpo prayer had some form of visual depictions of a cross or crucifix in his or her private sphere, serving as a visual aid and as a basis for recollection. We can, however, safely assume that the cross in his or her local church was visually accessible to the supplicant. Prominently displayed in a sacred surrounding in the local church, 
the large crucifix offered an elaborate setting that would have been of importance for the visual and devotional experience. ${ }^{19}$

The nave of the old wooden church in Torpo is still standing, and offers a partial glimpse of the devotional surroundings in Torpo. In the east part of the nave is a preserved vaulted canopy resting on columns, placed in front of the old entrance to the now demolished chancel (Figure 9). The canopy is the only surviving part of a medieval pulpitum. ${ }^{20}$ The vaulted canopy has a span of $4.6 \mathrm{~m}$ and a width of $2.15 \mathrm{~m}$. The back wall measures ca. $2 \mathrm{~m}$ at its highest (Brænne 1982, p. 196). The vault is covered in lavishly painted images made during the last half of the thirteenth century (Christie and Christie 1981, pp. 130-37). In the arched ceiling, Christ in Majesty is surrounded by the symbols of the Evangelists. On each side of Christ are the apostles, six in each row. In the bottom two rows, beneath the apostles, is a series of images depicting the martyrium of St. Margaret.

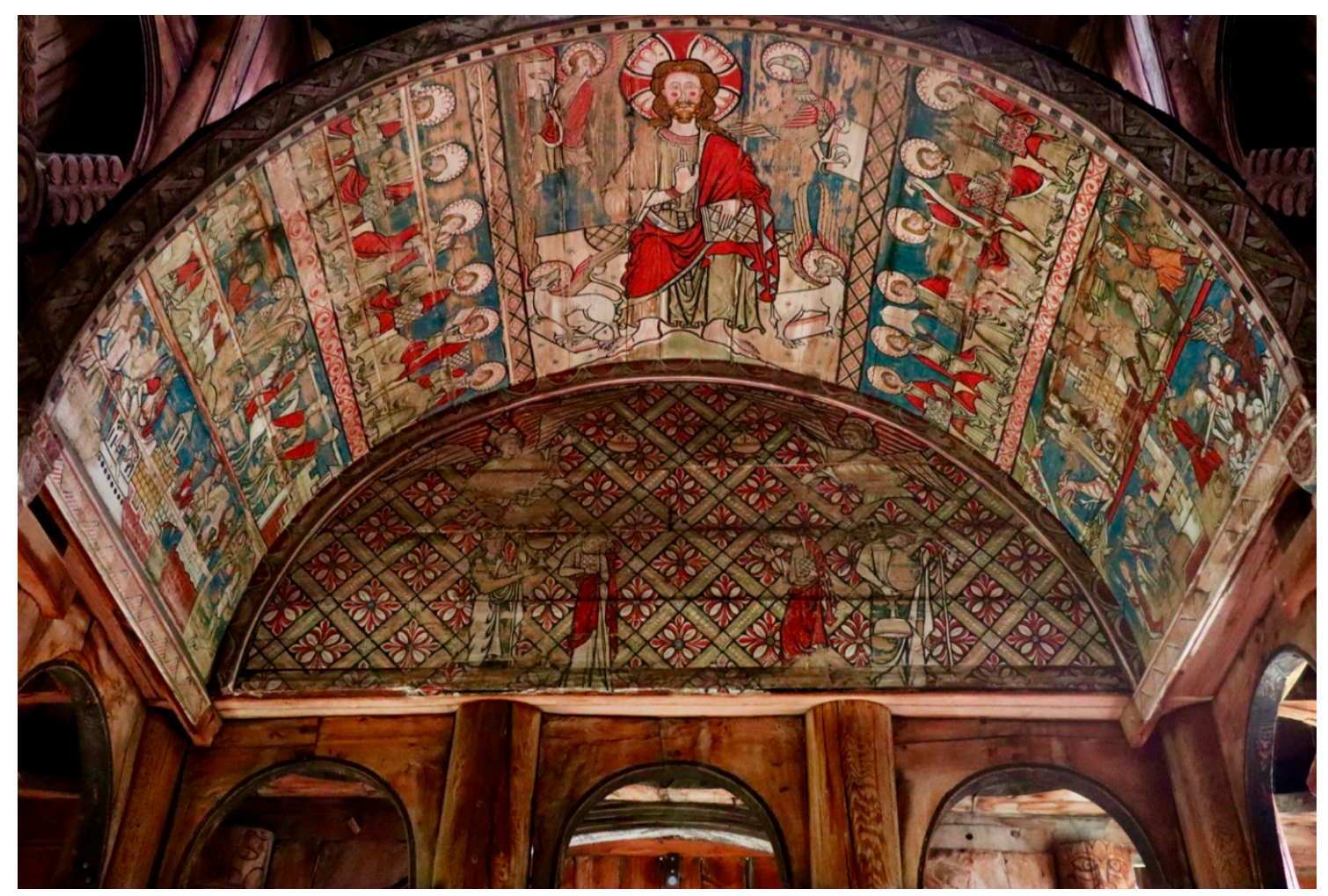

Figure 9. The Torpo canopy. Paintings from the thirteenth century. Photo: Kaja M. H. Hagen.

The back wall depicts figures from the crucifixion against a background of a square painted pattern with botanical ornamentation. To the left is the Virgin, who carries a book in her right hand, while her left hand rests against her cheek. To her right is a personification of the triumphant church, Ecclesia, holding the banner of the cross and a raised altar chalice. To the right is St. John, gesturing to the centre of the composition with one hand, carrying a book in the other. To his left is a personification of the Synagoga overthrown. Her head is bent, the pole of her banner is broken and the chalice turned upside down. Above them are facing angels holding censers in one hand while the other is pointing to the middle of the composition. The central figure, the cross or crucifix, is missing. Unlike the rest of the painted figures on the back wall, this was probably a three-dimensional crucifix placed in front of

19 According to Belting, the "crucifix was an elaboration of the preexisting cross" (Belting 1994, p. 299). In this article, I make no distinction between the cross and crucifix, as the apotropaic potential of a cross, present in both pictorial categories, assumedly would not have changed when the corpus of Christ was included.

20 Please see Linn W. Borgen's forthcoming Ph.-D. thesis. University of Oslo, Oslo, Norway. 
the painted motif where a tenon would have been tapped into the now missing vertical wall plate (Aavitsland 2016; and Stang 2008, pp. 161-66). ${ }^{21}$

Several medieval theological authorities in the Latin West have argued that crosses and crucifixes were to be treated separately from other categories of religious imagery and that such imagery required especial care and veneration (Cooper 2006, p. 48). Thomas Aquinas argued that not only images of Christ, but also of the cross, should be adored with latria, the highest mode of veneration (Aquinas n.d.b, ST, III, Q. 25 art. 3 and Laugerud 2005, pp. 66 and 72). However, both adoring an image with latria and venerating Christ himself involved a mental process that depended on recollection. For Aristotle and scholastic philosophers such as Thomas, visual images were the foundation for memory. In other words, we remember through images. When the bearer of the Torpo amulet addressed the cross in his or her prayers, either at home or in church, previously seen visual images of a cross were recollected. When venerating an image of a crucifix, previous memories and experiences of venerating both the prototype and memory of seen crucifixes were activated. In this manner, the physical images were prerequisites for mental images and a fundamental part of the devotional activity (Van Eck 2015, p. 72; Laugerud 2005). The now-lost great cross or crucifix present in the church of Torpo would have served as a focal point during prayers inside the church, but would also function as a mental imprint for the bearer of the prayer, and thus as a basis for a mental image he or she could recollect when praying to the cross outside of church.

The medieval cross was a polysemous object, embodying several layers of meaning-the cross was a symbol of the Christian faith and a referential object testifying to the crucifixion of Christ. The cross was also a mnemotechnical device serving as a mental imprint for the bearer inside and outside of church. The cross was an embellishment and an aesthetic work of art. The materials that the cross was made of could convey a meaning for the beholder: made from precious stones, materials, forms and colours invested with meaning, the allegorical potential of materials bore witness to God's presence in the world (Dahlerup 2010, p. 490 and Aavitsland 2015, p. 76). In addition, the cross could offer the pious an encounter with God and was believed to be capable of healing the supplicant or to ward off evil.

\section{The Power of the Object}

The pressing question when discussing the cross as an apotropaic or healing instrument, whether it is a textual amulet or a three-dimensional wonderworking cross, is where the power of the object was believed to come from. What made the object work? Was the object believed to be efficacious in itself, was it the immaterial divine power behind the object that made the object work—or a combination of the two?

The orthodox attitude towards images was that an image only referred to its divine prototype. An image was a sign pointing beyond itself and could be used as an aid in order to see the transcendent God. Prayers said in front of images were transferred to the holy persons depicted. This stance echoed formulations that went back to St. Basil in the fourth century, repeated at the Second Council of Nicea, by John of Damascus and Thomas Aquinas among others (Belting 1994, pp. 149-55; Laugerud 2005, pp. 64, 68; Maniura 2018, p. 64). Idolatrous warnings were reiterated by theologians throughout the Middle Ages. The authoritative theological attitude towards both textual amulets and religious imagery in respect to divine presence was the same-it was the transcendence of the object, understood as the underlying force, that made the objects work. God was the ultimate source of efficacy of both wonderworking crosses and textual amulets, and the objects were thus reduced to prosthetic aids.

21 The cross was most likely not fastened directly onto the back wall as there is neither discoloring in the pigments in the motif nor any signs of larger holes that would have been required in order to carry the weight of a large cross. There is a minor mark in the centre of the composition that might stem from a supporting mechanism for the once-standing cross. Please see Linn W. Borgen's forthcoming Ph.-D. thesis. University of Oslo, Oslo, Norway. 
The recognizable orthodox distinction between image and prototype was made by a Sienese sculptor, Lando di Piero, in 1338. He enclosed a piece of parchment in a sculpture of a crucifix he was working on that read:

Lord God made it possible for Lando di Piero of Siena to sculpt this cross from this wood in the likeness ['similitudine'], of the true Jesus Christ to recall for people the passion of Jesus Christ Son of God and of the Blessed Virgin Mary, therefore you true and holy cross of Jesus Christ Son of God, render the said Lando to God.

In addition to this plea, Lando added the following words:

The year of our Lord 1337 [1338 modern style], January, this figure was completed in the likeness ['similitudine'] of Jesus Christ crucified, true and living Son of God. And one should venerate him and not this wood. (Cooper 2006, pp. 47-48)

In line with authoritative theology, Lando urged people to look beyond the material image and venerate a prototype that was not present in the image.

One hundred and fifty years prior to Lando, in the 1230s, the bishop of Paris William of Auvergne wrote in his De legibus: “ $(\ldots)$ there are many simple folks $(\ldots)$ who make no distinction in their prayers between the images of saints and the saints themselves; nay those prayers which they should make to the saint they make to the image" (Maniura and Shepherd 2006, p. 8). William claims that an understanding of divine presence in religious imagery implied a cognitive error by "simple folks", most likely referring to (groups of) lay worshippers. William's statement indicates that lay people held opinions towards the ability of matter to disclose the divine that diverged from authoritative theology. Before discussing late medieval belief in the ontology of holy matter, let us look as William's statement concerning the various strata in society who held correspondingly different beliefs regarding the potential of objects and images.

As mentioned above, the presence of God in the world could be experienced in small glimpses on earth. Towards the later Middle Ages, the allegorical potential of images as pointers to an unseen transcendent truth was supplemented with a belief in the potential of divinity embodied in material objects, surpassing its symbolical or allegorical limitation. A multitude of images and objects all over Western Christianity were believed to be miraculous. The surviving written corpus on late medieval miracle working images is indeed vast (Freedberg 1989, pp. 299-301).

However, that the holy could reside in matter was far from universally accepted and was treated with ambivalence and sometimes condemnation by several learned theologians (Bynum 2011, chp. II). Certain cults, such as the blood-spotted wafers at Wilsnack, was criticized by several contemporary authorities (Bynum 2011, chp. II). According to Caroline W. Bynum, miraculous images made learned theologians uneasy and, as a result, they "jumped through intellectual hoops to avoid certain other implications of the idea that the holy is instantiated in matter" (Bynum 2011, p. 154). Hans Belting has stated that the philosophical and ontological difference between image and person depicted was of little interest to thinkers in the Latin west during the Middle Ages. The authority of miraculous images "lay rather in their unusual history rather than in their ability to be an incarnation of the person" (Belting 1994, pp. 304-8). Despite what motives have been assigned to late medieval theological thinkers in order to avoid the issue, the result was that the theology of holy matter was confusing and ambiguous (Bynum 2011, p. 164). According to Bynum: "Everyone condemned everyone else for misunderstanding how the divine intersected with the material, but no one denied that it did" (Bynum 2011, p. 165). It has been argued that highly intellectually and theologically defined beliefs, emphasizing the abstract, rational, systematic and dogmatic, stood in opposition to a more popular, irrational, emotional and object-based way of believing (Diedrichs 2005, pp. 34-35). But, as we shall see below, such a distinction is quite problematic.

Just as most people shared the understanding of the divine's ability to reside in matter (although by some restricted to the host and relics), the understanding of the human senses was most likely also 
shared by all strata of society. During the Middle Ages, experiences through human sensorium were believed to form the basis of all knowledge (Carruthers 2013, p. 17). As mentioned above, human sensory apparatus was structured and formed in order to apprehend the signs of God's presence in the world (Jørgensen 2015, pp. 25-31). By the later Middle Ages, a more practical way of believing, including perception and sense-based religious experiences, gained influence. People who had not necessarily had the education to access the intellectual dimension of the mysterium fidei, relied on their senses in their devotion (Diedrichs 2005, pp. 92-93). As a result of the acknowledgement of sense-based religious experiences, the role of images and objects was accentuated. Late medieval monstrances and reliquaries were designed to make hosts and relics visually accessible, testifying to the desire for visual contact between the pious and God. In a corresponding way, amulets served the need for haptic religious experiences. Images throughout western Christianity were held, kissed and in other ways venerated, in contact with human sensory apparatus. Artefacts such as images, sculptures, reliquaries and monstrances were material expressions of devotional practices that in most cases were facilitated, and thus sanctioned, within the ecclesiastical sphere. As mentioned above, amulets could also be produced by priests, monks and men and women of religious authority.

All of these examples illustrate a shared belief throughout the religious community both in the human hagiosensorium and in the potential of the holy to be instantiated in matter. Ecclesiastical authorities did indeed enable and sanction image worship and amuletic practices. Educated men and women of the church took part in the same culture as the uneducated, which makes it difficult to draw a hard line between all theologians on one side and lay people on the other. It has been argued that a distinctive line can only be drawn between a relatively small group of theologians of monastic circles whose writings have influenced our current understanding of the epoch today (Diedrichs 2005, p. 93). Instead of viewing theologians and lay people as two opposite and conflicting poles, perhaps a more nuanced and dynamic way of understanding the late medieval religious community is seeing the different arguments, understandings and practices as continuous negotiations to overcome disharmony.

When returning to the question of the ontology and perceptions as to what made an amulet effective, it cannot be ruled out that some bearers used the amulet as a prop accompanied neither by any devotional activity nor recognition of God as the working force behind the object nor a belief in a divinity present in the object. When amulets were used detached from religious understanding, the object could have been perceived as a magical device and hence in opposition to authoritative theology.

However, it must be assumed that a textual amulet containing a Christian prayer was most often used within a Christian context, with a belief in God working either in or through the object. The prototype addressed in the prayer written on an amulet was of course to be venerated. Presumably, the textual or visual content held a cognizance for the bearer, and attention was correspondingly given to the written and iconographical content of the amulet. Some preserved Norwegian amulets are made of lead, folded up in the shape of crosses and rectangles, with inscriptions inside. If opened up, the lead plates would have broken off, so any written content of such a lead amulet would not have been regularly read (Imer and Olesen 2018). In the same manner, if the carrier was illiterate, the content could not have been read by the bearer. If the content was in Latin, it is questionable if he or she fully understood the text.

However, that the words written on the amulet were not read does not necessarily mean that the carrier had no conscious awareness of its content. The prayers could have been read or explained for them when the amulet was made. Furthermore, as mentioned above, to read or hear someone else read the content of the amulet, was just one of several ways to perform a prayer. Amulets hung around the neck were visually and tactilely accessible with ease, and amulets placed in protective containers could have been taken out and seen, felt and handled as a part of a haptic devotional act. The material presence of the amulet, the feeling of the object on the body, could have served as a reminder to initiate further devotional activity. The amulet could also have served as a memory aid of the content known to the bearer. As mentioned above, rhyme and rhythm would have facilitated recollection. Perhaps the presence of the amulet would have urged the bearer to recite the verse learned 
by heart. In addition, the images drawn outside of both the Torpo and the parchment amulet, could have functioned as mnemotechnical aids of the content inside. It must then be assumed that veneration and devotion was indeed shown to God as He made the amulet effective in line with Thomas Aquinas' view discussed above.

Where does that leave the ontological status of the amulet? Was the amulet effective solely as a result of the veneration shown to the prototype? We have every reason to assume that the material presence of the amulet was believed to cause healing and an apotropaic effect. If not, then why bother with the material object at all? In order to shed light on the ontological belief in late medieval wonderworking objects, the next part of the article will draw comparable lines between amuletic practices and venerations of miraculous crosses.

\section{Amuletic Practices and Venerations of Miraculous Crosses}

In a European context, there are many stories of people addressing their prayers to a cross or crucifix and that in response, the image spoke, moved, bled or in other ways interacted with the worshipper (Bynum 2011; Freedberg 1989 and Maniura 2018, p. 64). Although the belief in divine presence was contested during the Middle Ages, it is hard to deny the belief in the agency of wonderworking images - they were, by many, understood to hold a capacity to act, influence and change the material world. Also in medieval Norway, many crosses and crucifixes were believed to be wonderworking.

Many medieval crosses were of obscure origins, often connected to acheiropoietic legends or legends where the cross had demanded to be placed in a specific church. These stories contributed to an understanding of the image as an independent agent, embodying a sacred presence. In Røldal, for example, several legends on the origins of the cross are preserved: one says that is was found in the mountains, three others that it was found at sea or in fjords. Despite their differences, all legends claim that it was the cross itself that expressed its will to be placed in Røldal church (Dalen 1960, pp. 74-77). These legends all contribute to an understanding that this image, not made by human hands, was elevated above similar depictions, and that the cross itself was able to articulate the will of God. In a comparable manner, the cross-prayer was believed to be written by pope Leo III or even Christ himself. The analogous holy origin of both wonderworking cross and the amuletic cross-prayer, served to elevate the ontology of both groups of objects.

To be in the proximity of the miraculous cross was paramount, and many holy crosses were locus for pilgrimage activity. In many cases, the cross should even be touched directly by the worshippers for increased efficacy. In Røldal for example, sweat from the crucifix would be wiped off by cloths and then pressed or fastened to the injured or sick parts of the bodies for healing. One of the most renowned miraculous crosses in Western Europe, is the Volto Santo of Lucca. The current crucifix is a thirteenth-century copy (Belting 1994, pp. 304-5 and Fishburne 2010, pp. 151-52), as the first crucifix was eroded as worshippers carved small pieces off the sculpture. The cross, and the many pieces carved from it, were thus treated like relics (Fishburne 2010). The understanding of the material presence of a wonderworking cross can therefore not be underestimated. To keep a part of the material object for personal use, carried on the body, whether a cloth with sweat or a piece of wood, was a testimony to the belief in the object per se. The similarities to amuletic practices are evident. Undoubtedly, the worshipper in Røldal believed it was God who made the sculpture sweat, it was God who made the crucifix efficacious. The prototype was not believed to be detached from the miraculous object. But at the same time, God had chosen to manifest himself through this particular object, elevating the ontology of the cross in question.

The visual difference between a small piece of paper and a large polychrome wooden cross is obvious. At first glance, the Torpo amulet is unimpressive, almost unnoticeable. Both the small size and the low-status medium of perishable paper limits its material and visual qualities. Meant for personal protection, the amulet was presumably kept inaccessible for other than the bearer. A large cross on the other hand, was invested with symbolic, referential and aesthetic value, in many cases a 
result of supreme craftmanship. A large cross was, based on the extant Norwegian material, made of wood, painted and could also be adorned with precious stones and gold and staged as the public focal point in the church.

Despite the apparent differences, a material cross and a textual amulet could conceptually express the same belief in the apotropaic powers of material objects. The apotropaic power of the cross addressed in the portable amulet was analogous to the power of the cross in church, and offered an expanded protection outside the ecclesiastical sphere, more far-reaching and personal than the immobile public cross in church, based on the proximity between bearer and object.

No one would claim that everyone in late medieval society shared a uniform and coherent opinion and set of beliefs regarding the ontology of religious objects. Rather, religious beliefs and practices were multifaceted, in some cases conflicting and constantly shifting. Many people may have believed in amulets and crosses in accordance with authoritative theology, that God worked through the object. At the same time, the potential for divine presence was understood to be there, under the surface of the material wonderworking object. The required physical connection between supplicant and material object testifies to a belief in the object itself. In this way, an amulet or a large cross in church could serve as a medium through which God could extend his power and establish a connection between Himself and the bearer. These objects were believed to make the sensuous divine accessible for humans, serving as holy locus-meeting point-between God and humans.

\section{Protection through a Plethora of Objects}

Textual amulets and large crosses were, however, not the only media that offered protection and healing. Above, we have seen that the Ave Gemma and the cross-prayer appeared both in amuletic form and in devotional books. A codex containing religious literature could be used amuletically to protect or cure and could, for example, be placed upon a sick person for healing. By the end of the Middle Ages, protection could be sought through a plethora of different objects, materials and practices, not only amulets and devotional and liturgical books, but also liturgical benedictions and relics, for example (Skemer 2006, pp. 57 and 68). There were, in other words, an abundance of complementary sources, understood as different paths all leading to the same goal.

This intermedial concept of protection can be observed in a preserved cross, now at the Museum of Cultural History in Oslo (C23299) (Figure 10). In 1923, a medieval silver double cross was found during construction work in Tønsberg, a town in the south east of Norway. The cross is only $7.1 \mathrm{~cm}$ tall with precious stones at the end of each cross arm. In the middle is a piece of wood still intact, most likely a relic from the True Cross. In the top vertical beam is a small ring through which a chain could be threaded. This object incorporates several aspects of how divine protection could be evoked-as mentioned above, the wood of the True Cross was believed to have miraculous powers already from the point of discovery. An inclusion of a relic from the True Cross would undoubtedly have enhanced the apotropaic qualities of the Tønsberg-cross. The preserved ring on top of the cross indicates that this was a pendant, meant to be carried around the neck, close to the body, analogous to that of a textual amulet. The Tønsberg-cross was thus both symbol and prototype, both a relic and amulet. 


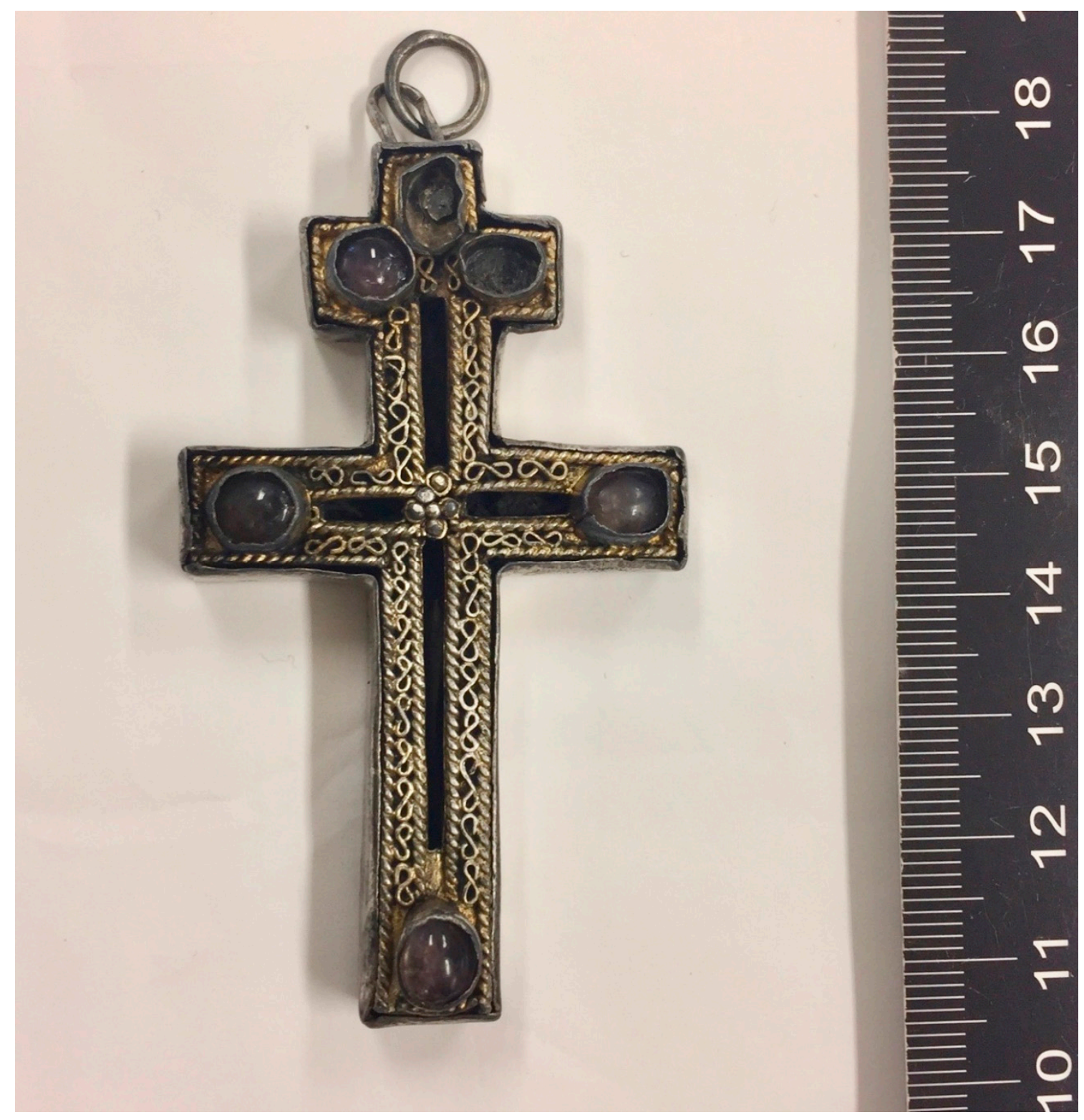

Figure 10. The Tønsberg cross. Silver and amethysts. H $7.1 \mathrm{~cm}$. In the middle of the cross is an extant piece of wood. Photo: Kaja M. H. Hagen.

\section{The Post-Reformation Understanding of Miraculous Crosses}

In 1536-1537, Norway was made subject to the Danish crown and the new Lutheran faith was implemented in the new kingdom of Denmark-Norway. The introduction of Protestantism entailed a revised attitude towards earthly matter as carrier of the divine. The medieval veneration of matter was, according to Luther, a deceitful staging carried out by the papal church in an attempt to control the faithful beholder. Yet Luther never dismissed the idea of matter as a potential carrier of the divine. Rather, his defense of the ubiquity of Christ implied an omnipresence of God, a presence without limits imposed by time or space (McGrath 1999, p. 189 and Luther 1989, pp. 64-65). By denoting Christ's own words in Matthew 26: 26, hoc est corpus meum, Luther confined God's presence to the Eucharist (Luther 1989, p. 82).

Prior to the Reformation, the anchoring of Lutheran ideas and belief was minimal among the Norwegian population and the old beliefs and practices continued for several decades, and in some cases centuries (Kolsrud 1939; Oftestad et al. 1993; Imsen 2016 and Laugerud 2018). What happened to 
the venerated images and amulets under the new paradigm? In the following, religious instruction, didactic texts, Luther's own words and studies of the Lutheran priests' practical work in early modern Denmark-Norway will shed light on the post-Reformation understanding and treatment of amulets and miraculous crosses in Norway.

As Norway became subject to the Danish crown, religious instructions and regulations penned in Denmark also applied to Norway. In line with Luther's own writings, Danish religious instructions, such as the Church Ordinance of 1537 and the visitation book written by the influential bishop and reformer Peder Palladius, stated that images that were worshipped in an incorrect manner were to be removed or burned. Palladius' visitation book offers a glimpse of what was regarded as false or wrong veneration: (i) images that were sought out, most likely referring to extra-liturgical cultic images, images that were believed to embody a divine presence and images which attracted pilgrims, (ii) images that received gifts in the form of wax dolls, understood as votive offerings, and (iii) images that the faithful hang crutches on, most likely referring to the practice of leaving crutches after healing in the presence of a miraculous image (Palladius 2003, pp. 39 and 141). All other images were to remain in church. The congregation was to be instructed in the correct understanding of images-images could be useful as didactic tools and aesthetic objects, but could not offer the pious a glimpse of the divine. An image was nothing but lifeless matter, not a medium between God and humans.

Thirty years after the Reformation, the religious and spiritual changes in Norway were limited, however (Kolsrud 1939). In 1572, in order to educate the people on the correct understanding of images, the bishop in Bergen, Jens Skielderup, published a didactic book formed as a dialogue between a peasant and a priest. Skielderup was clearly inspired by more image-hostile theologians, such as Niels Hemmingsen and John Calvin. The peasant articulates Luther's more tolerant view on images, while the priest, lecturing to the ignorant peasant, paraphrases Calvin and Hemmingsen. The peasant asks why the images cannot remain in the church, as they do neither good nor harm (Skielderup 1572/1905, pp. 34f). This argument is easily recognizable as a Lutheran adiaphora-argument. But the priest cannot accept this stance-not everyone possesses the wisdom to know that images are simply dead pieces of wood, ("døde Træstytter") deprived of sacredness. An image is indeed harmful if someone worships it, the priest explains. The peasant continues, wanting to know why images cannot remain as "biblia pauperum" in accordance with Gregory the Great's view. The priest dismisses this old and well-known justification of images, claiming that this argument was not anchored in the bible (Skielderup 1572/1905, p. 38f). "How about the crucifix? Can one have a crucifix?", the peasant presses on. And the priest reluctantly answers, "If you were to have an image on the altar, it should be a crucifix" (Skielderup 1572/1905, p. 53f). Skielderup reasons that a crucifix would be acceptable-but he dared not decide this definitely as he feared the wrong use of such an image and explicitly warns against the idolatry caused by the crosses in "Fana, Oppdal, Røldal and Austad and many other places in Norway" (Skielderup 1572/1905, pp. 53-54). ${ }^{22}$ This passage sheds light on several aspects of the early Protestant understanding of holy crosses: firstly, it testifies to the understanding that many crosses in medieval Norway were indeed venerated; secondly that the practice continued after the Reformation; thirdly, that even in the strictest post-Reformation writings, crosses and crucifixes seem to have been accepted - as long as they were not venerated.

It is questionable how much influence Skielderup's book gained. Despite Skielderup's attempt to implement a new attitude towards images and despite the theological instructions mentioned above, it seems that many of the crosses connected to unaccepted veneration remained in the churches. Most likely, their potential for didactic functions secured their prolonged ecclesiastical presence. Today,

22 Translated by the author. Original text: "Skulde mand haffue nogen Lignelse eller Billede paa Alteret/da maatte det heldst være it Crucifix/Thi efferdi alting som der handlis/bør at lyde om Christo alene/saa skulde oc Bemalingen eller Billedet være om hannem: Men her tør jeg intet beslutte/Thi den hellige Scrifft lyder intet der om/oc Christus oc Apostlerne vise oss til Ordet/mand skal oc befrycte at der kand opkomme med tiden saadan Vrangbrug der hoss/som skede udi Paffuedommit hoss kaarssit i Fane/Opdal/Rørigedal/Eustad/oc mange andre steds her i Norge." 
as mentioned above, as many as 170 crosses have survived, and among them are 10 of the crosses that the sources show as receiving pilgrims and gifts. The famous sweating crucifix from Røldal was visited by pilgrims seeking healing up to the nineteenth century, and is still in situ.

We do not know if the cross that was once a part of the Calvary group in Torpo was in any way venerated against the Lutheran instructions. Today, the cross is missing, but we do not know why and when it was removed. It has been suggested that the Calvary group once formed the backdrop for a cross altar. ${ }^{23}$ After the Reformation, the numerous altars in churches were to be removed as a church was to have one altar only (Palladius 2003, p. 39). It is a possibility that the Torpo cross was removed or relocated as the probable cross altar was deconstructed. Perhaps the cross was damaged, or it may simply have gone out of fashion and was replaced by the newer seventeenth-century crucifix currently hanging in the church. It cannot, however, be ruled out that the cross was removed as a result of unacceptable veneration. It seems strange to leave the iconographical motif, the Calvary Group-a motif that seem to have been accepted even by image-hostile Lutheran theologians-without the most central piece, the crucifix. There must have been weighty reasons for removing the crucifix and hence leaving the rest of the composition incomplete.

\section{The Post-Reformation Understanding of Textual Amulets}

The Torpo amulet was made just years before the Reformation was implemented in Norway. Not only false veneration of images, but also the use of textual amulets was strongly condemned by Luther and later Lutheran theologians. To write the opening words of John or the words 'Thesus Nazarenus Rex Judeorum' on a piece of paper and hang it in a container around the neck-as seen in both the Torpo amulet and the parchment amulet-was used as a prime example by Luther to illustrate misuse and religious malpractice (Luther 1957, pp. 106-7). Luther associated the practice of textual amulets with witchcraft and sorcery. To believe that a piece of paper hung around the neck could protect the bearer was, according to Luther, "customary in the papacy" and a godless act (Skemer 2006, p. 67).

The same rhetoric was used by Danish theologians. In Niels Hemmingsen's 1575 book on witchcraft and demonology, Admonitio de superstitionibus magicis vitandis, Hemmingsen states that written words, signs and symbols held no power (Gilje and Rasmussen 2002, p. 249). In the same book, he also states that benedictions, either performed orally or written down, could indeed influence humans and nature, he would not deny that, but it was always the Devil who was responsible. In all forms of magic, benevolent or malevolent, the devil was the causa efficiens (Gilje and Rasmussen 2002, pp. 248-50).

During the Middle Ages, the term 'magic' was, as mentioned earlier in the article, reserved for demonic magic. After the Reformation, the term was used for both benevolent and malevolent practices, the first category encompassing all forms of religious activities not in line with Lutheran theology. Remaining medieval devotional practices-including amuletic devotion-were labelled superstitio and demonic magic according to authoritative Lutheran theology. ${ }^{24}$

Although Thomas Aquinas accepted the use of some amulets if veneration was shown to God as the working force behind the object, theological opposition to amulets could also be found in the Middle Ages (Skemer 2006, p. 58-66). Luther and Lutheran theologians' attack on the use of amulets is, however, a break with medieval theology, as amuletic practices were described as demonic sorcery

23 Please see Linn W. Borgen's forthcoming Ph.-D. thesis. University of Oslo, Oslo, Norway.

24 In an educational book from 1601, Hemmingsen and Reravius equates "blessings, measurings and writings for diseases" with ungodly acts, and the people performing such activities as corrupted by the Devil (Hemmingsen and Reravius 1601/1618. Please also see Helge A. Staxrud's forthcoming Ph.-D. thesis. University of Oslo, Oslo, Norway.) The original text in the introduction to the 1618 edition of the book, Reravisu writes "Gunstige Læser/denne undervisning om den store oc gruelige Guds bespottelse/som skeer met Troldom/signelse/manelse/oc anden saadan vanbrug/er saare fornøden/vel at betracte/effterdi Dieffuelen stedse oc altid tracter at forføre Menniskene/til all vrang oc falsk Tro oc mening/til Troldom/Signelse/Maalelse/manelse/spaadom/ oc anden saadan Guds allerhelligste Naffns oc Ords vanbrug/saa at vi maa vel beklage det alt formeget/mere end sanden at være/det den hellige Apostel Paulus/udi sin Epistel til de Epheser/i det andet Capitel/udi sin tid klager/saa sigendis: Dieffuelen haffuer i denne tid sin Gierning $i$ Vantroens Børn. Item/til Timothæum i den anden Epistel/Cap ii. siger hand om de Ugudelige/at de ere fangne aff Dieffuelen/effter hans Villie." 
under the new paradigm. The belief in sorcery and witchcraft in the post-Reformation society was real and people did believe in the efficacy of magic (Gilje and Rasmussen 2002, p. 242). Theological condemnation of textual amulets could be seen as an attempt to control and constrain the evil powers, but categorizations and accusations of magic, witchcraft and sorcery can also be understood as social, cultural and/or religious constructions, in line with Lutheran efforts to change the old beliefs and practices still valid among common people.

However, recent studies of the role of the early modern Lutheran priest indicate that the normative ideal expressed in the vast corpus of early Lutheran writings could be far from the practical everyday challenges facing the priests in the parishes. Despite their efforts in convincing the parishioners with persuasive arguments in favour of the new faith, old practices and beliefs, intertwined in the daily life of most people, were difficult to eradicate. Authoritative Lutheran theology was in several instances interpreted and negotiated in order to adapt to local traditions and rituals (Appel and Fink-Jensen 2009), and it cannot be ruled out that some priests looked the other way when it came to amuletic practices.

We know that many of the old religious practices continued for a long time after the Reformation, as was probably also the case with amulets. In 1584, a citizen of the high society in Stavanger sought help for his wife who was believed to have been afflicted by maleficium. In order to help her, a man known to have "magical" skills were summoned, and he carved five crosses into the woman's flesh (Gilje and Rasmussen 2002, pp. 241-43). ${ }^{25}$ This story reveals several aspects of religious beliefs in the post-Reformation society: firstly, that the apotropaic belief in the cross persisted for decades after the Reformation; secondly, that practices of haptic devotion correspondingly continued; thirdly, that the cognitive universe of haptic devotion and apotropaic crosses was shared by both high and low classes in Norwegian society also after the Reformation; and fourthly, that the understanding of how forces in the world worked remained the same across the confessional change-God was responsible for the good in the world, and the Devil for the bad, such as diseases and accidents (Gilje and Rasmussen 2002, p. 239). Amuletic practices and amulets were devotional tools that armed the bearer against the ever-present disasters, dangers and daemons both before and after the confessional change.

In 1901/1902, the Lutheran theologian Anton Chr. Bang collected the content and use of textual amulets and related devotional practices in Norway from the thirteenth century up to that point (Bang 1901/1902). The largest part of the collection are medical and practical advices. Two aspects of this work are of particular interest for this study. Firstly, many prayers and practices collected and recorded in the book from the nineteenth century do indeed resemble medieval devotional activities. Of course, it cannot be claimed that all the prayers, rubrics and formulas in Bang's collection are of medieval origin or that they are blueprints of medieval practices. Nonetheless, there are many similarities—several prayers are addressed to the Virgin, such as prayers in hope for relief from toothache (Bang 1901/1902, pp. 532-33). Furthermore, many rubrics are similar to the medieval ones. The material shows that many prayers were to be written down and carried on the body. Secondly, the book's title is Witch Formulas and Magical Recipes. ${ }^{26}$ When the amulet from Torpo was registered in the Diplomatarium Norvegicum, it was, in a corresponding manner, described as "sorcerous spell or amulet". ${ }^{27}$ To label remnants of medieval devotional activities as sorcery, seem to have an accepted principle of classification, also in the nineteenth century. In this article, I seek to argue that in its original context, the Torpo amulet was a material expression of the bearer's devotion, a medium between God and man and a belief in the healing and protective power of the cross, not an instrument of witchcraft.

25 The story of the crosses carved into the woman's flesh, reached Jørgen Eriksen, the bishop in Stavanger. He addressed this incident with King Fredrik II who issued a law against practices such as carving of crosses, benediction and readings that were to help against diseases. For practitioners of such magic, the penalty was death, without mercy (Gilje and Rasmussen 2002, p. 244). Original text: "Folk befindes, som enten at bruge eller gjøre saadanne forargelig ukristelig Middel, enten med Kors, Signelse, Lxrning og anden saadan ugudelige og ukristelig Handel, ( . . ) da at skulle lade dennem straffe paa Livet uden al Naade (... .)."

26 Original title: Norske Hexeformularer og magiske Opskrifter.

27 Original text: "benyttet som Trylleformular eller Amulet", Diplomatarium Norvegicum, 12, no. 266. 
It is reasonable to assume that the understanding of the Torpo amulet was in continuance with medieval devotional practices for a long period after the Reformation, as we know that the old beliefs did persist, but we cannot know for how long. Disrupted from Rome, over time the Catholic religious and spiritual influence became meagre, and we cannot rule out that the once devotional tool could have been used for other ends.

In Vinje, a small village in the south of Norway, the old church was demolished and a new one erected at the end of the eighteenth century. During the demolition, medieval parchment leaves, many of them dated from around 1480, were found under the wooden boards in the chancel. These texts were later published under the name The Book from Vinje. The Eldest Book on Black Magic from the Norwegian Middle Ages (Garstein 1993). ${ }^{28}$ The first part of the book contained medical and practical advice. Some were accompanied with rubrics and incantations in order to increase the effect. The next part contained hymns to the Virgin, a fragmentarily preserved legend of the Virgin and prayers directed to saints. The greater part of this book was in other words not a book of black magic, at least not in its original context. The categorization of the book as altogether sorcery is best understood as another expression of Lutheran condemnation towards remnants of Catholic devotional practices.

The Torpo prayer was found in 1880, but we do not know when it was placed in the church. Would it be possible for a piece of paper to lie under the floor for centuries without deteriorating? Is it possible that the Torpo prayer was placed under the floor boards shortly before the demolishment of the chancel? Could the Torpo amulet have continued to function as an amulet or perhaps as a birth-girdle for women in the community for years, perhaps centuries after the Reformation?

It is not only The Book from Vinje and the amulet from Torpo that were found in churches. Amulets have also been found under the floor in both Borgund stave church and Årdal church for example (Bang 1901/1902, p. 470). If textual amulets were condemned by the Protestant clergy and believed to be objects of black magic, the obvious question is why these objects were placed and hidden inside churches. It is hard to imagine that it was possible to place a manuscript or an amulet under the floorboards in the church's chancel without the acceptance or at least the knowledge of the act by the local priest. One explanation could be that the priest sought control over these unwanted objects. But why were the amulets simply not thrown away or burned? Could the placement inside the church be understood as a recognition of the power of the written word after all? A rubric before a prayer to St. Dorothy in the Danish prayer book AM 418, $12^{\circ}$ may shed light on the placement of the Torpo prayer. The rubric reads "In that house, where her image [St. Dorothy] is written, that house will not be damaged by fire" ${ }^{29}$ The amulet could thus have been placed inside the church for protection from fire.

\section{Concluding Remarks}

The small textual amulet in Torpo was made at the end of the fifteenth century, when Norway was still a part of the Roman church, and while the belief in apotropaic agency of both amulet and cross was still rooted among the faithful. In its original context, the Torpo amulet was an object of devotion, carried as a material expression of the cross' capacity to protect and heal the pious. After the Reformation, amulets were labelled as objects for demonic and magical use. To describe the textual amulet from Torpo as a device used in magic and witchcraft, is to disregard the function and the meanings ascribed to it in its original context.

During the Middle Ages, multiple functions and layers of meaning were incorporated in the image of the cross. The cross was a symbol of the redemption of humankind, a didactic symbol, a referential image of the crucifixion and an aesthetic embellishment. The cross was also a miraculous object offering healing and protection to the faithful. Many crosses and crucifixes in medieval Norway

28 Original title: Vinjeboka. Den eldste svartebok fra norsk middelalder.

29 (Nielsen 1946-1982, II. 327). Translated by the author. Original text: "Och huilket hws hennes belethe er screuenth wthi Thet hws maa ey worthe ild skadhe". 
were believed to be wonderworking. As we have seen, many amulets, also in a Norwegian context, had crosses inscribed, were made in shape of crosses or contained prayers addressing the cross.

Protection could be sought from a variety of practices and material objects, not only textual amulets and large wonderworking crosses. These two categories of objects seem nevertheless to have accentuated the apotropaic and healing potential offered by the cross, and both categories of objects were treated as a meeting place between God and humans with a capacity to influence the lives of the pious.

We do not know to whom the Torpo prayer belonged, neither do we know when it was placed in the chancel of the church. We do know, however, that the prayer was not thrown away or burned, but transferred back to the realm of the sacred. Perhaps this act can be interpreted as a persisting belief in the power originally ascribed to the amulet.

Funding: This research received no external funding.

Acknowledgments: I am much indebted to Laura K. Skinnebach for sharing her knowledge on devotional culture in late medieval Denmark-Norway, for insightful comments and interesting discussions during the writing process. I am also much grateful to Vemund Blomkvist who helped me translate the Latin texts to English. Many thanks are also due to Linn W. Borgen for helping me shed light on the canopy in Torpo, to Helge A. Staxrud for interesting discussions on post-Reformation magic and witchcraft, to Halfdan Baadsvik for helping me translate the Torpo amulet from Latin to Norwegian, to Karen Holmqvist for information about amulets written in runes and to Elise Kleivane for valuable input on medieval manuscript production. I am as always grateful to my supervisors Kristin B. Aavitsland and Sivert Angel for valuable comments and suggestions during the writing process.

Conflicts of Interest: The author declares no conflict of interest.

\section{References}

\section{Primary Sources}

AM 429 12mo. 1490-1510. Legends of Female Martyrs (Kirkjubæjarbók). Copenhagen: Den Arnamagnæanske Samling. Available online: https://handrit.is/en/manuscript/view/en/AM12-429 (accessed on 1 July 2019).

Aquinas, St. Thomas. 1951. Commentary on Aristotle's De Anima. Translated by Kenelm Foster O.P., and Sylvester Humphries O.P.. New Haven: Yale University Press.

Aquinas, St. Thomas. Summa Theologica, Part II-II (Secunda Secundae) and III (Tertia). Available online: http: //www.gutenberg.org/ebooks/18755andhttp://www.gutenberg.org/ebooks/19950 (accessed on 1 July 2019).

Diplomatarium Norvegicum. Available online: https://www.dokpro.uio.no/dipl_norv/diplom_felt.html (accessed on 1 July 2019).

Hemmingsen, Niels, and Rasmus Hansen Reravius. 1601/1618. En Undervisning aff den Hellige scrifft, hvad mand døme skal om den store oc gruelige Guds bespottelse, som skeer met Trolddom, Sinelse, Manelse oc anden saadan Guds hellige Naffns oc Ords vanbrug: Item 33 Propositiones imod Troldom. Der til 33 Propositiones om Spaadom. Kiøbenhaffn: Salomone Sartorio.

Huitfeldt, Henrik J. 1879. Biskop Eysteins Jordebog: (Den røde Bog). Fortegnelse over det geistlige Gods i Oslo Bispedømme omkring Aar 1400. Christiania: J. Chr. Bogtrykkeri.

Leo, Pope, III. 1633. Enchiridion Leonis Papae ... Imp. Carolo Magno ... Datum. Nuperrime Mendis Omnibus Purgatum/ Leo III] Mainz, S.n.]. Available online: https://search-proquest-com.ezproxy.uio.no/docview/ 2090367616? accountid=14699 (accessed on 1 July 2019).

Luther, Martin. 1957. Sermons on the Gospel of St. John. In Luther's Works. Edited by Jaroslav Pelikan. St. Louis: Concordia Publishing House, chp. 1-4. vol. 22.

Luther, Martin. 1989. Verker i Utvalg: 5. Edited by Inge Lønning and Tarald Rasmussen. Oslo: Gyldendal.

Munch, Peter A. 1834a. Registrum prædiorum et redituum ad ecclesias dioecesis Bergensis sæculo P.C. XIV.to, pertinentium, vulgo dictum "Bergens Kalvskind" (Bjørgynjar Kalfskinn). Christianiae: Guldberg \& Dzwonkowski.

Munch, Peter A. 1834b. Aslak Bolts Jordebog: Fortegnelse over Jordegods og andre Herligheder tilhørende Erkebiskopsstolen i Nidaros. Christiania: C. Grøndahl. 
Nicolaysen, Nicolay. 1862-1866. Norske fornlevninger. Utgivet af Foreningen til norske fortidsmindesmærkers bevaring. Kristiania: Carl Werner \& comp's bogtrykkeri.

Nielsen, Karl Martin. 1946-1982. Middelalderens Danske Bønnebøger. Copenhagen: Gyldendal, vol. 1-5.

Nielsen, Yngvar. 1885. Biskop Jens Nilssøns Visitatsbøger og Reiseoptegnelser 1574-1597. Udgivne efter offentlig foranstaltning ved Dr. Yngvar Nielsen. Kristiania: A.W. Brøgger.

Palladius, Peder. 2003. En Visitasbog. Udgivet på nud Ansk Med Inledning og Noter af Martin Schwarz Lausten. København: Forlaget Anis.

Regesta Norvegica. Available online: https://www.dokpro.uio.no/dipl_norv/regesta_felt.html (accessed on 1 July 2019).

Skielderup, Jens. 1572/1905. En Christelig Underuisning aff den Hellige Scrift. Edited by Fredrik B. Wallem. Christiania: Det Mallingske Bogtrykkeri.

Sperber, Ingrid, ed. 2019. Breviarium Nidrosiense. Oslo: National Library of Norway. Available online: https://www.bokselskap.no/wp-content/themes/bokselskap2/tekster/pdf/breviarium.pdf (accessed on 15 September 2019).

Steinsland, Gro. 2004. Draumkvedet og Tekster fra Norrøn Middelalder. Oslo: De Norske Bokklubbene.

\section{Secondary Sources}

Aalholm, Olav Anton. 1957. Er snart vår 600-årige pergament-amulett fra Bringsvær i Fjære? In Aust-Agdermuseets Årbok 1957. Arendal: P.M. Danielsens Trykkeri.

Aavitsland, Kristin Bliksrud. 2015. Incarnation. Paradoxes of Perception and Mediation in Medieval Liturgical Art. In The Saturated Sensorium. Principles of Perception and Mediation in the Middle Ages. Edited by Hans Henrik Lohfert Jørgensen, Henning Laugerud and Laura Katrine Skinnebach. Århus: Aarhus University Press.

Aavitsland, Kristin Bliksrud. 2016. The Church and the Synagogue in Ecclesiastical Art: A Case from Medieval Norway. Eologisk Tidsskrif 5: 324-39. [CrossRef]

Appel, Charlotte, and Morten Fink-Jensen. 2009. Når det Regner på Præsten. En Kulturhistorie om Sognepræster og Sognefolk, 1550-1750. Højbjerg: Hovedland.

Bang, Anton Chr. 1901/1902. Norske Hexeformularer og Magiske Opskrifter. Kristiania: I Commission Hos Jacob Dybwad.

Belting, Hans. 1994. Likeness and Presence: A History of the Image before the Era of Art. Chicago: University of Chicago Press.

Bertelsen, Dag. 2016. Kirker i Glemselens slør. Søkelys på det Norske Kirkelandskapet i Middelalderen. Jakobsli: D. Berthelsen.

Brendalsmo, Jan. 2007. Deserted Churches and Migratory Legends about Churches towards an Understanding. In Arv. Stockholm: Almqvist \& Wiksell, vol. 63.

Brænne, Jon. 1982. Torpo stavkirke-Problemer omkring konserveringen av det dekorerte middelalderlektoriet med tilhørende baldakin. In Polykrom Skulptur og Maleri på træ (Volume 2 of Kompendium). København: Nordisk Ministerråd, (Kompendium 2).

Bynum, Caroline Walker. 2011. Christian Materiality. An Essay on Religion in Late Medieval Europe. New York: Zone Books.

Carruthers, Mary. 2013. The Experience of Beauty in the Middle Ages. Oxford: Oxford University Press.

Christie, Haakon, and Sigrid Christie. 1981. Norges Kirker: 1: Buskerud. Oslo: Land og kirke.

Cooper, Donal. 2006. Projecting Presence: The Monumental Cross in the Italian Church Interior. In Presence. The Inherence of the Prototype within Images and Other Objects. Edited by Robert Maniura and Rupert Shepherd. Aldershot: Ashgate.

Dalen, Knut. 1960. Alma. 1960: Røldal Bygdebok. Røldal: Røldal kommune.

Dahlerup, Pil. 2010. Sanselig Senmiddelalder. Litterære Perspektiver på Danske Tekster 1482-1523. Århus: Aarhus Universitetsforlag.

Davies, Owen. 2012. A Very Short Introduction to Magic. Oxford: Oxford University Press.

Diedrichs, Christof L. 2005. Desire for viewing. "A Deluge of Images" in the Middle Ages. In Genre and Ritual. The Cultural Heritage of Medieval Rituals. Copenhagen: Museum Tusculanum Press. 
Fishburne, James. 2010. Renaissance Devotion and the Volto Santo of Lucca. Comitatus: A Journal of Medieval and Renaissance Studies 41: 149-66. [CrossRef]

Freedberg, David. 1989. The Power of Images: Studies in the History and Theory of Response. London: University of Chicago Press.

Garipzanov, Ildar. 2018. Graphic Signs of Authority in Late Antiquity and the Early Middle Ages, 300-900. Oxford: Oxford University Press.

Garstein, Oscar. 1993. Vinjeboka. Den Eldste Svarteboka fra Norsk Middelalder. Oslo: Solum forlag.

Gilje, Nils, and Tarald Rasmussen. 2002. Tankeliv i den lutherske stat. In Norsk Idehistorie. Oslo: Aschehoug, vol. 2. Gjerløw, Lilli. 1959. Aust-Agder-Arkivets middelalderlige håndskriftsfragmenter. In Aust-Agder-Arv. Arendal: P.M. Danielsens Trykkeri.

Hahn, Cynthia. 2011. Inscriptions and Interactions: Text and Image on the Cloisters Cross and other Ivories. Acta ad Archaeologiam et Artium Historiam Pertinentia 24: 185-204. [CrossRef]

Hohler, Erla. 2017. Medieval Wooden Sculpture in Norway. In Collegium Medievale. Interdiciplinary Journal of Medieval Research. Oslo: Society for Medieval Studies, vol. 30.

Imer, Lisbeth M., and Rikke S. Olesen. 2018. In the Beginning was the Word: New Finds of Lead Amulets in Denmark. In Epigraphy in an Intermedial Context. Edited by Alessia Bauer, Elise Kleivane and Terje Spurkland. Dublin: Four Courts Press.

Imsen, Steinar. 2016. Da Reformasjonen Kom til Norge. Oslo: Cappelen Damm.

Jensen, Robin M. 2017. The Cross. History, Art, and Controversy. Cambridge: Harvard University Press.

Jessen, Mads D., and Tim Flohr Sørensen. 2015. Embodiment and Senses in Eleventh to Thirteenth-Century Churches in Southern Scandinavia. In The Saturated Sensorium. Principles of Perception and Mediation in the Middle Ages. Edited by Hans Henrik Lohfert Jørgensen, Henning Laugerud and Laura Katrine Skinnebach. Århus: Aarhus University Press.

Jørgensen, Hans Henrik Lohfert. 2015. Into the Saturated Sensorium. In The Saturated Sensorium. Principles of Perception and Mediation in the Middle Ages. Edited by Hans Henrik Lohfert Jørgensen, Henning Laugerud and Laura Katrine Skinnebach. Århus: Aarhus University Press.

Karlsen, Espen. 2013. Latin Manuscripts of Medieval Norway: Studies in Memory of Lilli Gjerløw. Oslo: Novus Press. Kieckhefer, Richard. 1989. Magic in the Middle Ages. Cambridge: Cambridge University Press.

Kolsrud, Oluf. 1939. Folket og Reformasjonen i Noreg. Bergen: A.S. John Greigs Boktrykkeri.

Laugerud, Henning. 2005. Det Hagioskopiske Blikk. Bilder, Syn Og Erkjennelse I Høy-Og Senmiddelalder. Ph.D. dissertation, University of Bergen, Bergen, Norway.

Laugerud, Henning. 2018. Reformasjon uten folk. Det katolske Norge i før-og etterreformatorisk tid. Oslo: St. Olav Forlag.

Maniura, Robert, and Richard Shepherd. 2006. Presence: The Inherence of the Prototype Within Images and Other Objects. Aldershot: Ashgate.

Maniura, Robert. 2018. Agency and Miraculous Images. In The Agency of Things in Medieval and Early Modern Art: Materials, Power and Manipulation. Edited by Ika Matyjaszkiewicz, Grażyna Jurkowlaniec and Zuzanna Sarnecka. London: Routledge.

McGrath, Alister E. 1999. Reformation Thought. An Introduction. Oxford: Blackwell.

Oftestad, Bernt, Tarald Rasmussen, and Jan Schumacher. 1993. Norsk Kirkehistorie. Oslo: Universitetsforlaget.

Samnordisk Runtextbas. Available online: http://www.nordiska.uu.se/forskn/samnord.htm (accessed on 15 September 2019).

Skemer, Don C. 2006. Binding Words. Textual Amulets in the Middle Ages. University Park: Pennsylvania State University Press.

Skinnebach, Laura K. 2013. Practices of Perception. Devotion and the Senses in Late Medieval Northern Europe. Ph.D. dissertation, University of Bergen, Bergen, Norway.

Skinnebach, Laura K. 2019. Haptic Prayer. Devotional Books and Practices of Perception. In Touching. Devotional Practices and Visionary Experience in the Late Middle Ages. Edited by David Carrillo-Rangel, Delfi I. Nieto-Isabel and Pablo Acosta-Garcia. London: Palgrave Macmillan.

Stang, Margrethe C. 2008. Body and Soul: The Legend of St Margaret in Torpo Stave Church. In Ornament and Order. Essays on Viking and Northern Medieval Art for Signe Horn Fuglesang. Edited by Kristin B. Aavitsland and Margrethe C. Stang. Trondheim: Tapir Akademisk Forlag. 
Trexler, Richard C. 1972. Florentine Religious Experience: The Sacred Image. In Studies in the Renaissance. Chicago: University of Chicago Press on Behalf of the Renaissance Society of America, vol. 19. Available online: https://www.jstor.org/stable/2857086 (accessed on 3 April 2019).

Van Eck, Caroline. 2015. Art, Agency and Living Presence: From the Animated Image to the Excessive Object. Boston: de Gruyter.

Wolf, Kirsten. 1997. The Icelandic Legend of Saint Dorothy. Toronto: Pontifical Institute of Mediaeval Studies.

(C) (1)

(C) 2019 by the author. Licensee MDPI, Basel, Switzerland. This article is an open access article distributed under the terms and conditions of the Creative Commons Attribution (CC BY) license (http://creativecommons.org/licenses/by/4.0/). 